\title{
Structural Breaks in Volatility: Evidence for the OECD and non-OECD Real Exchange Rates
}

\author{
Amalia Morales-Zumaquero \\ (University of Málaga and Centro de Estudios Andaluces) \\ Simon Sosvilla-Rivero \\ (Universidad Complutense de Madrid)
}

\begin{abstract}
This paper attempts to determine whether or not nominal exchange rate regimes affect the volatility of bilateral and effective real exchange rates. To that end, we examine the real exchange rate behaviour for a set of OECD and non-OECD countries during the 1960-2006 period, therefore covering both the Bretton Woods system of fixed exchange rates and adoption of generalised floating exchange rates from 1973. We make use of an econometric methodology based on the Hansen (1997)'s approximation to the $p$-values of the supreme, exponential and average statistics developed by Andrews (1993) and Andrews and Ploberger (1994). This methodology allows us to obtain a profile of $p$ values and to delimit periods of stability and instability in the variance of real exchange rates. Results suggest that there is clear evidence in favour of the non-neutrality of nominal exchange rate regime regarding real exchange rate volatility for developed countries, but not in the case of developing or emerging countries.
\end{abstract}

JEL Classification Numbers: F31, F33, F41

Keywords: Exchange rate regimes, bilateral and effective real exchange rates, volatility

Full postal addresses:

Amalia Morales-Zumaquero: Departamento de Teoría Económica, Facultad de Ciencias

Económicas y Empresariales, Campus de El Ejido s/n, Universidad de Málaga, 29013

Málaga, Spain.E-mail: amalia@uma.es

Simón Sosvilla-Rivero: Departamento de Fundamentos del Análisis Económico II, Facultad de Ciencias Económicas y Empresariales, Universidad Complutense de Madrid, Campus de Somosaguas, 28223 Madrid, Spain, E-mail: $\underline{\text { sosvilla@ccee.ucm.es }}$ 


\section{Introduction}

An important empirical question in international finance concerns the stability of real exchange rate (RER) volatility. Particularly, it is of interest to investigate the behaviour of the RER volatility under different nominal exchange rates arrangements. There is a strong theoretical ${ }^{1}$ and empirical academic debate on this issue, being the previous evidence mixed. On the one hand, Mussa (1986), Baxter and Stockman (1989), Flood and Rose (1995), Rogers (1995), Liang (1998) and Carrera and Vuletin (2003), among others, find a positive relation between RERs volatility and the degree of flexibility of the nominal exchange rate regime. However, on the other hand, Grilly and Kaminsky (1991) find that the distribution of the monthly rate of change of the RER is the same under fixed and floating regimes for the pre-World War II data, but different for the post-World War II data. Thus, they conclude that the RER behaviour depends on the particular historical period, rather than upon the nominal exchange rate regime. Moreover, Kent and Naja (1998) examine the relationship between the short-term volatility of the real effective exchange rate (REER) and the degree of the flexibility of the nominal exchange rate. Based on pooled results across a set of countries, they find that the REER is only twice volatile under floating regimes than under fixed regimes. Results within countries show that for most countries there is no significant increase in volatility when moving to more flexible exchange rate regimes and, indeed, there are even some countries in which volatility is lower under more flexibility exchange rate regimes. Thus, from previous literature we would like to remark that there is not a clear consensus on the connection between exchange rate regimes and RER volatility. This

\footnotetext{
${ }^{1}$ For a further discussion on theoretical advances on this issue see Carrera and Vuletin (2003) and Bastourre and Carrera (2004).
} 
issue is of relevance because the RER volatility looks to have important effects on macroeconomics variables (Frankel and Rose, 1995).

This paper tries to shed some light on the RER behaviour using an alternative data set and a new econometric methodology than the one used in the previous literature. For this end, two samples of twenty-two OECD and twenty non-OECD countries for the 1960-2006 period are considered, therefore covering both the Bretton Woods system of fixed exchange rates and adoption of generalised floating exchange rates from 1973. The two groups of countries have marked differences on macroeconomic stability, constituting an interesting scenario for comparison.

The approach taken here marks a departure from traditional literature on the non-neutrality of nominal exchange rate regime regarding real exchange rate volatility. Specifically, we sequentially apply tests for a structural change in variance to a range of possible breakpoints, therefore avoiding us to assume a prior knowledge of its location. Our strategy to monitoring a structural change in variance is based on the Hansen (1997)'s approximation to the $p$-values of the supreme, exponential and average statistics developed by Andrews (1993) and Andrews and Ploberger (1994). We will apply this methodology following the approach proposed by McConnell and PérezQuirós (2000) and Camacho (2004). This approach allows us to obtain a profile of $p$ values and to delimit periods of stability and instability in the variance of not only the bilateral RERs but in the variance of the REERs too.

For most OECD countries in our sample, our results identify a first period of stability in the variance of the RER until early/mid 1970s, following by a period characterised by strong evidence of instability in the variance. Therefore, the results seem to suggest that changes in the RER volatility would have been linked to a specific nominal exchange rate regime, giving support to the non-neutrality hypothesis of 
nominal exchange rate regime regarding real exchange rate volatility. In contrast, there is not a clear pattern RER volatility and exchange rate regime for the non-OECD countries, suggesting that macroeconomic performance and financial developments could play a significant role in the relationship between those two variables.

The paper is organised as follows. Section 2 presents the econometric methodology used for testing structural breaks in the RER volatility. Section 3 describes the data set. Section 4 reports our empirical results. Finally, Section 5 provides some concluding remarks.

\section{Econometric Methodology: Testing for Structural Breaks in Volatility}

Our analysis to detect structural breaks in volatility is based on univariate autoregressive models for first differences (growth rates) of the real exchange rate series, which we denote as $q_{t}$. Following McConnell and Pérez-Quirós (2000) and Camacho (2004), we compute, at any quarter (month) $t$, the GMM estimates of the specification

$$
\begin{aligned}
& q_{t}=\mu+\phi q_{t-1}+\varepsilon_{1 s} \\
& \sqrt{\frac{\pi}{2}}\left|\hat{\varepsilon}_{1 s}\right|=\alpha_{1} D_{1 s}+\alpha_{2} D_{2 s}+\varepsilon_{2 s}
\end{aligned}
$$

where the dummies are 


$$
\begin{aligned}
& D_{1 s}=\left\{\begin{array}{l}
0 \text { if } s \leq T \\
1 \text { if } s>T
\end{array}\right. \\
& D_{2 s}=\left\{\begin{array}{l}
1 \text { if } s \leq T \\
0 \text { if } s>T
\end{array}\right.
\end{aligned}
$$

and $s$ refers to data of the period from 1960 to $s$, the instruments for each period $s$ are a constant, $q_{t}, D_{1 s}$ and $D_{2 s}, T$ is the estimated break point and $\alpha_{1}$ and $\alpha_{2}$ are the estimators of the standard deviation. ${ }^{2}$

Andrews (1993) and Andrews and Ploberger (1994) develop statistics for cases similar to the previous one, where the parameter $T$ appears under the alternative hypothesis but not under the null of constant conditional standard deviation $\left(\alpha_{1}=\alpha_{2}\right)$. They define the function $F_{n}(T)$ as the Wald (W), Likelihood Ratio (LR) or Lagrange Multiplier (LM) statistic of the hypothesis that $\alpha_{1}=\alpha_{2}$, for break date $T$, where $n$ is the number of observations. We assume that $T$ lies in a range $T_{1}, T_{2} \cdot{ }^{3}$ Specifically, Andrews (1993) considers the supreme statistic:

$$
\text { Sup } F=\sup _{T_{1} \leq T \leq T_{2}} F_{n}(T)
$$

where $F=\mathrm{W}$, LR or LM.

On the other hand, Andrews and Ploberger (1994) consider the exponential and average statistics, given by the following expressions:

$$
\operatorname{Exp} F=\ln \left(\frac{1}{T_{2}-T_{1}+1} \sum_{T=T_{1}}^{T_{2}} \exp \left(\frac{1}{2} F_{n}(T)\right)\right)
$$

$$
\text { Ave } F=\frac{1}{T-T+1} \sum_{T=1}^{T_{2}} F_{n}(T)
$$

${ }^{2}$ If $\varepsilon_{t}$ follows a normal distribution, $\sqrt{2}\left|\hat{\varepsilon}_{t}\right|$ Ps an tunbiasêd estimator of the standard deviation of $\varepsilon_{t}$ (see McConnell and Pérez-Quirós, 2000, and Camacho, 2004).

${ }^{3}$ We set $T_{1}=.15 \mathrm{n}$ and $\mathrm{T}_{2}=.85 \mathrm{n}$ (see Andrews, 1993 and Andrews and Ploberger, 1994). 
where $F=\mathrm{W}$, LR or LM.

The asymptotic distributions of these statistics are non-standard and have been obtained by Andrews (1993) and Andrews and Ploberger (1994), together with their asymptotic critical values. In this paper we apply these statistics, using the associated $p$ values obtained following the approximation developed by Hansen (1997). In particular, we will perform an out of sample test, compute the $p$-values associated with the supreme, exponential and average statistics for any quarter, and obtain a profile of $p$ values to be plotted. In doing so, we will have numerical and graphical information that will be used to delimit periods of stability and instability of the R(E)ER volatility.

\section{Data}

In the empirical analysis, we use monthly/quarterly data ${ }^{4}$ of the consumer price index and the end of period bilateral nominal exchange rates against the United States Dollar (USD) to construct the bilateral real exchange rates for our set of OECD and non-OECD countries, covering the 1960-2006 period. ${ }^{5}$ Moreover, from previous data, we construct real effective exchange rates for each country, covering the 1960-2006 period, as a trade-weighted average of bilateral RERs with those trading partners encompassing 4 per cent or more of trade in either exports or imports. ${ }^{6}$ The trade weights are fixed and have been taken from Goldfajn and Valdés (1999). The OECD countries are Australia, Austria, Belgium, Canada, Denmark, Finland, France, Germany,

\footnotetext{
${ }^{4}$ The data frequency depends on availability. See Appendix.

${ }^{5}$ The selected countries under study depends on data availability. With the beginning of Economic and Monetary Union (EMU) in 1999, the currencies of Austria, Belgium, Finland, France, Germany, Ireland, Italy, Luxembourg, The Netherlands, Portugal and Spain disappeared, being replaced by the Euro. Therefore, the sample period for these countries only covers the 1960-1998 period.

${ }^{6}$ This way of constructing REERs is the usual practise followed by the International Monetary Fund, the European Central Bank and the Deutsche Bundesbank, among others institutions.
} 
Greece, Ireland, Italy, Japan, Korea, Luxembourg, The Netherlands, New Zealand, Norway, Portugal, Spain, Sweden, Switzerland and United Kingdom. The non-OECD countries are Burkina Faso, Chile, Colombia, Cyprus, Dominican Republic, El Salvador, Egypt, Haiti, India, Israel, Ivory Coast, Jamaica, Sri Lanka, Malta, Morocco, Philippines, South Africa, Trinidad and Tobago and Venezuela. ${ }^{7}$

The data used in this paper came from the IMF International Financial Statistics of the International Monetary Fund and the OECD Main Economic Indicators.

\section{[Insert Figures 1(a) and 1(b) here]}

Figures 1(a) and 1 (b) plot the first log differences of the monthly/quarterly RERs against the United States Dollar during the period 1960-2006 and Figures 2(a) and 2(b) plot the first log differences of the monthly/quarterly REERs during the period 1960-2006. A simple look at Figures 1(a) and 2(a) for the OECD countries show the differences in the RER volatility during and after the Bretton Woods periods. In particular, during the Bretton Woods fixed exchange period (1960 to 1973), the RER volatility is much smaller than in the post-Bretton Woods, flexible exchange rate period. However, this behaviour does not graphically emerge in the set of real exchange rates for the non-OECD group of countries.

[Insert Figures 2(a) and 2(b) here]

\footnotetext{
${ }^{7}$ We do not construct the effective real exchange rate for the OECD countries Austria and Luxembourg and the non-OECD countries Chile, Cyprus, Dominican Republic, El Salvador, Egypt, India and Malta due to the lack of trade weights data for those countries.
} 


\section{Empirical Results}

\subsection{A First Interpretation of Results}

Empirical results on changes in the real exchange rate volatility are shown in Tables 1 to 4 and in Figures 3 and 4.

\section{[Insert Tables 1 to 4 here]}

Tables 1 (3) and 2 (4) report the periods of stability/instability detected for the variance of real (effective) exchange rates for our sets of OECD and non-OECD countries, respectively. First and second columns indicate the country and the sample period, ${ }^{8}$ columns three to five offer a summary of results regarding the $p$-values. In particular, they indicate whether the $p$-values from the supreme ( $p v s u p)$, the exponential (pvexp) and the average (pvave) statistics are up or below the standard 0.05 critical value. In several cases, we indicate whether the $p$-values are in the interval $[0.05,0.10]$. The sixth column indicates if there is or not evidence in favour of instability in the variance of real exchange rates during the sub-period indicated in column two. In general, we conclude that there is evidence of instability in the variance of the series when at least two out of the three statistics are below the 0.05 critical value. In addition, we conclude that there is marginal evidence of instability when the $p$-values are in the interval $[0.05,0.10]$. Figures 3 and 4 show the results regarding the $p$-values graphically.

$$
\begin{aligned}
& \text { [Insert Figures 3(a) and 3(b) here] } \\
& \text { [Insert Figures 4(a) and 4(b) here] }
\end{aligned}
$$

Table 1 and Figure 3(a) report the results regarding bilateral RERs for the OECD countries. We can identify two potential groups of countries with different RER volatility characteristics. A first group of countries show successive sub-periods of RER 
stability and RER instability, being the break point located around 1973. This group is formed by Australia, Belgium, Denmark, France, Germany, Greece, Ireland, Italy, Japan, Luxembourg, Norway, Portugal, Sweden, Switzerland and United Kingdom. ${ }^{9}$ Canada and Spain could also be included in this group, although the break point occurs latter (1979 and 1981, respectively). In the case of Spain, this break point coincides with the introduction of a de facto crawling around the Deutschmark [see Reinhart and Rogoff (2004) and Ledesma-Rodríguez et al. (2007)]. On the other hand, there is a second group of countries, with an initial period of stability, followed by a period of instability, then a period of renewed stability and, finally, a further period of instability. In those countries, in addition to the break point around 1973, a first period of instability is found between the end of 1960 s and $1971 .{ }^{10}$ This group includes Austria, Finland, The Netherlands and New Zealand. ${ }^{11}$ Korea presents also this pattern, although the second break point is located in 1967 instead of 1973, where a period of quasi-flexible regime started with the US dollar (Reinhart and Rogoff, 2004).

As for the non-OECD countries, Table 2 and Figure 3(b) show the results for the bilateral RERs. In this case, RER volatility characteristics could be summarised in five potential groups of countries. Once again, we can identify a first group of countries, with successive sub-periods of RER stability and RER instability, being the break point located around 1973. This group includes Burkina Faso, Sri Lanka, Malta and South Africa. A second group of countries is formed by Cyprus, Chile, El Salvador, Haiti and

\footnotetext{
${ }^{8}$ The sample starts at 1963 instead of 1960 because we compute the p-values starting from a sample of twelve observations.

${ }^{9}$ The detected instability around 1963 in Australia and Norway disappear when we repeat the analysis with more initial observations (i.e., for the period 1957.I-2003.IV and 1957.01-2003.12, respectively). Thus, this apparent instability at the beginning of the sample would just indicate the insufficient power of the statistics when applied to a small initial sample. Nevertheless, this instability could be related to the reserve problems experienced by the United Kingdom.

${ }^{10}$ The detected instability around 1964 in Finland disappear when we repeat the analysis with more initial observations (i.e., for the period 1957.I-1998.IV).

${ }^{11}$ Note that in 1967, the New Zealand dollar substituted the New Zealand pound, being the new currency pegged to the Pound sterling (Reinhart and Rogoff, 2004).
} 
Morocco, where we detect also a single transition from stability to instability, although the break point occurs in 1981, 1963, 1990, 1984 and 1979, respectively. There is a third group with an initial period of stability, followed by a period of instability, then a period of renewed stability and, finally, a further period of instability. This group includes Honduras and Jamaica, being the break points located in 1965 and 1988, and in 1978 and 1984, respectively. A fourth group of countries emerges, were there is a succession of recursive periods of stability and instability. This group includes Colombia, Egypt, Ivory Coast, Philippines, Trinidad and Tobago and Venezuela. Finally, the results for India indicate that there has been stability through all the sample and those for Israel suggest that after an instability period covering the 1963-1971 period, a stability period opens from 1971. Therefore, there is not a clear relationship between precise changes in the nominal exchange rate regimes and the detected break points for almost all non-OECD countries, leaving open the possibility that there may have been some other event unrelated to the nominal exchange rate regime (real shocks, shifts in international demand, monetary policy instability, discovery of new natural resources, etc.) contributing to the change in RER volatility.

Regarding the REER volatility, the results for the OECD countries are depicted in Table 3 and Figure 4(a), while those for the non-OECD countries are presented in Table 4 and Figure 4(b). In general, results are similar to the previous ones using bilateral RERs, except for the cases of Australia, Colombia, Ivory Coast and Norway (where now there is only a break point), Burkina Faso, Greece and Phillipines (where now there are two break points) and Spain (where a new stability period opens after EU accession in 1986). Therefore, all in all, the empirical evidence suggests that the instability obtained is robust to the real exchange rate used. 
As for the interpretation of the detected periods of instability, in the first place, the 1973 breaking point could be associated with the breakdown of the Bretton Woods system and the advent of floating exchange rates (see, i.e., Cooper, 1999). This break point appears in all countries using the bilateral or effective RERs.

Secondly, the instability period detected between the end of 1960s and 1971 could be clearly associated with the third realignment experimented by the Bretton Woods system at the end of 1960s and the general Smithsonian realignment at the end of 1971. It is interesting to note that during 1967 the Switch pound was abolished after being operating from 1950, leading to devaluation and a monetary turmoil. On the other hand, after the United States suspended convertibility of the Dollar into gold in August 1971, an effort was made, in the Smithsonian Agreement of December 1971, to reestablish a stable per value structure of exchange rates. A multilateral realignment of exchange rates was negotiated to eliminate the overvaluation of the Dollar that had developed during the Bretton Woods par values regime, by devaluing the Dollar and appreciating the central rates of the currencies of the other major industrial countries. Not many months after the Smithsonian Agreement, exchange markets again became volatile and disorderly.

Finally, as a further attempt to link the timing of changes in the volatility of RER to the timing of changes in the nominal exchange rate regime, we have tried to document whether or not the instability episodes have been associated with flexible exchange rate regimes. To that end, we have made used of the coarse grid classification of exchange-rate regimes provided by Reinhart and Rogoff (2004) for our selection of countries and sample periods. In particular, we have considered five broad regime categories: fixed, quasi-fixed, quasi-flexible, freely floating and freely falling. ${ }^{12}$

\footnotetext{
${ }^{12}$ In Reinhart and Rogoff (2004) there is a sixth category named "dual market in which parallel market data is missing", but there are no observations under such regime for the countries and sample period
} 
Since our results for instability are detected using data are vis-à-vis the USD and some of the countries under study have taken other currencies as references for pegs, in the last column of Tables 1 and 2 we report only the regime against the USD in order to facilitate the interpretation. Therefore if, for example, the Belgian franc is classified by Reinhart and Rogoff (2004) during the1974.2-1975.6 period as a de facto peg to Deutsche Mark and the latter is freely floating against the USD, we conclude that the Belgian franc was freely floating vis-à-vis the USD. The same procedure is used for the REERs taking into account the main trading partners in order to determine the exchange rate regime against the USD.

For the OECD sample, results in Table 1 indicate that in 29 out of the 38 cases stability episodes were associated with fixed exchange rates, being 5 of the remainder subperiods linked to quasi-fixed exchange rates and the other 4 to quasi-flexible regimes. As for the instability episodes, in 35 out of 72 cases they were associated with freely floating, in 21 cases with quasi-flexible regimes, in 7 cases with quasi-fixed regimes and in 9 cases with fixed exchange rates.

Regarding the non-OECD countries (Table 2) ${ }^{13}$, in 19 out of the 57 cases for which we have information, stability episodes were associated with fixed exchange rates, 31 cases with quasi-fixed exchange rates and the 7 remainder cases with to quasiflexible regimes. For the instability episodes, in 7 out of 62 cases they were associated with freely falling, in 12 cases with freely floating, in 18 cases with quasi-flexible regimes, in 17 cases with quasi-fixed regimes and in 8 remainder cases with fixed exchange rates.

examined. Data are available at Carmen Reinhart's web page:
http://www.wam.umd.edu/ creinhar/Links.html regimes in Ivory Coast and Trinidad y Tobago, we cannot analyse these countries. 
As for the REER results, Table 3 shows a strong association between instability episodes and freely floating (35 out of 53 cases) and between tranquil sub-periods and fixed exchange rates (22 out of 37 cases) for the OCED countries, while Table 4 suggests that, for the non-OECD countries under study, although there is evidence of a clear connection between tranquil sub-periods and fixed exchange rates (15 out of 27 cases), the relationship between instability episodes and freely floating is much weaker (9 out of 26 cases).

All in all, this empirical evidence seems to suggest that tranquil periods were associated with fixed or quasi-fixed exchange rates for both groups of countries, while instability episodes were more likely to be found under freely floating or quasi-flexible regimes in the OCDE sample but not necessarily for the non-OECD countries under study.

\subsection{An Alternative Interpretation of Results: A Further Analysis}

An alternative interpretation of the detected volatility changes is that it could be generated not so much by a flexible nominal rate regime, but rather by the fact that a fixed exchange rate regime was maintained for "too long", requiring a very large adjustment of the real exchange rate (via a change in the nominal exchange rate) ${ }^{14}$. From this point of view, much of volatility in a more flexible exchange rate regime might be driven by an initial realignment of the RER in response to misalignment under the earlier more fixed exchange rate regime. This is not to say that all fixed exchange rate regimes lead to misalignment and the more so the longer it has been in place. Instead, this is an argument about the level of the RER being far from fundamental levels, and that this forces a move to a flexible nominal exchange rate regime, with an initial period during which the nominal and real exchange rate are extremely volatile.

\footnotetext{
${ }^{14}$ We are very grateful to a referee for pointing out this point.
} 
In order to empirically explore this possibility, we perform two complementary analyses. In first place, we try to confirm that volatility in sub-periods with evidence of instability is higher than in more tranquil episodes. In second place, we estimate GARCH models incorporating regimen duration in the variance equation.

$$
\text { [Insert Tables 5(a) to 5(d) here] }
$$

Regarding to the first analysis, Tables from 5(a) to 5(d) report the results of excluding initial periods once a jump up in volatility is detected for OECD and nonOECD countries. As can be seen, for OECD countries in almost all cases (19 out of the 22 possible cases) $)^{15}$ results suggest that those sub-periods where we have found evidence in favour of instability do show higher volatility than more stable sub-periods. For non-OECD countries the evidence is mixed: there are 8 out of the 17 possible cases in which instable sub-periods exhibit higher volatility than in more tranquil sub-periods, 7 out of the 17 possible cases in which this results is confirmed for several sub-periods for the same country, and just 2 out of the 17 possible cases in which this result is not supported by the data. Similar evidence are found using REER data.

Regarding the second analysis, we have estimated $\operatorname{GARCH}(1,1)$ models incorporating regimen duration in the variance equation: ${ }^{16}$

$$
\begin{aligned}
& r_{t}=c+\varepsilon_{t} \\
& \sigma_{t}^{2}=\varpi+\alpha \varepsilon_{t-1}^{2}+\beta \sigma_{t-1}^{2}+\lambda d_{t}
\end{aligned}
$$

where $r_{t}=\log \left(q_{t} / q_{t-1}\right)$ and $d_{t}$ denotes regime duration, computed as number of periods (quarters or months) that a given exchange-rate regime has been in operation at time $t$.

\footnotetext{
${ }^{15}$ Note that in the other 3 out of the 22 possible cases (Austria, Netherlands and New Zealand), this result is confirmed in one of the sub-periods.

${ }^{16}$ We also examined other $\operatorname{ARCH}(\mathrm{p})$ and $\operatorname{GARCH}(\mathrm{p}, \mathrm{q})$ specifications, but the $\operatorname{GARCH}(1,1)$ model was preferred both in terms of both the log likelihood and the AIC and SIC model selection criteria (see Sin and White, 1996).
} 
To compute $d_{t}$ we have used abovementioned Reinhart and Rogoff (2004)'s coarse grid classification.

$$
\text { [Insert Table 5(e) here] }
$$

Table 5(e) reports the estimated coefficients for $d_{t}(\hat{\lambda})$ and the probability numbers ( $p$-values) of the associated $z$-statistics. Note that we have excluded in our analysis Ivory Coast and Trinidad y Tobago since Reinhart and Rogoff (2004) do not offer information on the evolution of exchange rate regimes for these countries. As can be seen, for the RER in the OECD countries duration has a positive effect on volatility in 18 out of the 22 cases analysed (being significant in 12 cases), while only in the 4 remain cases we find a negative effect (but only significant for The Netherlands). In contrast, for the RER in the non-OECD countries we obtain a negative effect on volatility in 14 out of the 18 cases considered (being significant in 12 cases) and only in the 4 remain cases a positive impact is detected (being only significant for Dominican Republic, Egypt and Jamaica). A similar pattern arises for the REER data. Therefore, our findings suggest that while for the OECD countries longer regime durations are associated with increasingly R(E)ER volatility levels, for non-OECD countries the opposite seems to be true.

\section{Concluding Remarks}

In this paper we have attempted to contribute to the wide and active research programme on the behaviour of real exchange rate (RER) volatility under different nominal exchange rate regimes. This is an important question given the strong effect of RER volatility on several macroeconomic variables such as consumption, investment 
and trade flows (Frankel and Rose, 1995) or even on the long-term growth path (Rodrik, 2000). In particular, we have examined the changes in the bilateral and effective RER volatility registered in twenty OECD industrial countries and twenty non-OECD developing countries, during the 1960-2006 period, therefore covering both the Bretton Woods system of fixed exchange rates and adoption of generalised floating exchange rates from 1973. To that end, we departure from previous research in this area by using an econometric methodology based on the Hansen (1997)'s approximation to the $p$ values of the supreme, exponential and average statistics developed by Andrews (1993) and Andrews and Ploberger (1994). This methodology allows us to obtain a profile of $p$ values and to delimit periods of stability and instability in the variance of real exchange rates.

The main results are as follows. First, we found a group of seventeen out of the twenty two OECD industrial countries examined where the profile of the $p$-values exhibits a first period of stability in the RER volatility followed by a second period of instability. In addition, there is a second group formed by the remainder five countries which present a very similar profile of $p$-values: a first period of stability, a second period of instability, a third period of stability and a fourth period of instability in the variance of the RER. Regarding the break point from stability to instability is located (mostly) around 1973 for the first group of countries, when the practice of fixing exchange was generally abandoned by the major countries. This break point also appears in the change of RER volatility in the second group of countries between the third period of stability to the fourth period of instability. Our results suggest that these countries would have also experienced a previous RER instability period between the end of 1960s and 1971 associated with the third and the general Smithsonian realignments, respectively. 
Second, in this case of the non-OECD developing countries, a clear pattern does not emerge: in nine out of the twenty cases considered we find a single transition from RER stability to RER instability; in other two cases, we detect an initial period of stability, followed by a period of instability, then a period of renewed stability and, finally, a further period of instability; in other six cases we observe a succession of recursive periods of stability and instability; in one case we obtain evidence of stability through all the sample and in the remain case we find a transition from instability to stability. As for the break points, only in four out of the twenty cases examined we identify the breakdown of the Bretton Woods system in 1973 as a potential explanation of the change in the RER volatility. For the rest of developing countries, there is not a clear relationship between precise changes in the nominal exchange rate regimes and the detected break points, thus leaving open the possibility that there may have been some other event unrelated to the nominal exchange rate regime contributing to the change in RER volatility.

Third, the evidence of instability obtained for the bilateral and effective real exchange rates is very similar, therefore suggesting that our results are robust to the real exchange rate used.

For the OECD countries, we could interpret our result as evidence in favour of the non-neutrality hypothesis of nominal exchange rate regime regarding real exchange rate volatility, since the period of stability is detected until early/mid 1970s and was followed by a new period exhibiting strong evidence of instability in RER variance.

This in turn could suggest that the change in the RER volatility would have be linked to a specific nominal exchange rate: the transition from a fixed nominal exchange rate regime to a flexible nominal exchange rate regime after the collapse of the Bretton Woods system. Moreover, the instability detected by the end of 1960 and 1971 in six 
out of twenty countries can be associated with realignments in the Bretton Woods system. Thus, we could conclude that for our set of OECD industrial countries the evidence suggests a parallel movement of nominal and real exchange rates. In contrast, there is not a clear pattern RER volatility and exchange rate regime for the non-OECD countries, suggesting that macroeconomic performance and financial developments could play a significant role in the relationship between those two variables.

Our results also show a notorious difference in terms of RER volatility according to the degree of development of the country. This finding is in line with recent discussion on dynamics of exchange rate regimes, where it is argued that the more financially developed part of the world has been able to exploit to its fullest possible extent its ability to float, while the less financial developed ones have always faced serious difficulties due to the "original sin" and "hollowing out" hypotheses (see, e. g., Hausman et al., 1999).

Furthermore, while for OECD countries the empirical evidence presented in this paper seems to suggest that instability sub-periods show higher volatility than more stable sub-periods, for non-OECD countries the evidence is mixed. On the other hand, our results indicate that stability periods are associated with fixed or quasi-fixed exchange rates for both groups of countries, while instability episodes are more likely to be found under freely floating or quasi-flexible regimes in the OCDE sample but not necessarily for the non-OECD countries under study.

Finally, our findings suggest that the relationship between RER volatility and regime duration could be quite different depending on the particular macroeconomic conditions experienced by both group of countries, since we obtain that for the OECD countries greater regime duration is associated with increasingly $\mathrm{R}(\mathrm{E}) \mathrm{ER}$ volatility levels, while for non-OECD countries the opposite seems to be true. 


\section{Acknowledgements:}

The authors are grateful for the financial support received from the Centro de Estudios Andaluces (Project ECO-9) and from the Spanish Ministry of Science and Technology (SEJ2005-09094/ECON), and for helpful comments and valuable suggestions received from two anonymous referees and the editor, as well as from the participants in the IV Workshop on International Macroeconomics (Málaga, 2004), in the 4th Annual Conference of the European Economics and Finance Society (Coimbra, 2005), in the IX Jornadas de Economía Internacional (La Laguna, 2005), in the XIII Foro de Finanzas (Madrid, 2005) and in the 61st International Atlantic Economic Conference (Berlin, 2006). Balázs Égert and Eduardo Ley kindly provided us with the data set used in this paper. Any remaining errors are entire our responsibility. The views expressed here are those of the authors and not necessarily those of the institutions with which they are affiliated. 
Appendix: Data frequency and period covered

\begin{tabular}{|c|c|c|c|c|}
\hline \multicolumn{2}{|l|}{ Country } & Frequency & Period RER & Period REER \\
\hline \multicolumn{2}{|l|}{ OECD } & & & \\
\hline Australia & AUL & Quarterly & 1960.I-2003.IV & 1960.I-2003.IV \\
\hline Austria & AUT & Monthly & 1960.3-1998.12 & - \\
\hline Belgium & BEL & Monthly & 1960.3-1998.12 & 1960.3-1998.12 \\
\hline Canada & CAN & Monthly & $1960.3-2006.12$ & $1960.3-2006.12$ \\
\hline Denmark & DEN & Quarterly & 1960.I-2003.IV & 1960.I-2003.IV \\
\hline Finland & FIN & Quarterly & 1960.I-1998.IV & 1960.I-1998.IV \\
\hline France & FRA & Monthly & 1960.3-1998.12 & 1960.3-1998.12 \\
\hline Germany & GER & Monthly & 1960.3-1998.12 & 1960.3-1998.12 \\
\hline Greece & GRE & Monthly & 1960.3-1998.12 & 1960.3-1998.12 \\
\hline Ireland & IRE & Quarterly & 1960.I-1998.IV & 1960.I-1998.IV \\
\hline Italy & ITA & Monthly & 1960.3-1998.12 & 1960.3-1998.12 \\
\hline Japan & JAP & Monthly & 1960.3-2006.12 & 1960.3-2006.12 \\
\hline Korea & KOR & Monthly & 1960.3-2006.12 & 1960.3-2006.12 \\
\hline Luxemburg & LUX & Monthly & 1960.3-1998.12 & - \\
\hline Netherlands & NET & Monthly & 1960.3-1998.12 & 1960.3-1998.12 \\
\hline Norway & NOR & Monthly & 1960.3-2006.12 & 1960.3-2006.12 \\
\hline New Zealand & NZL & Quarterly & 1960.I-2003.IV & 1960.I-2003.IV \\
\hline Portugal & POR & Quarterly & 1960.I-1998.IV & 1960.I-1998.IV \\
\hline Spain & SPA & Monthly & 1960.3-1998.12 & $1960.3-1998.12$ \\
\hline Sweden & SWE & Monthly & 1960.3-2006.12 & 1960.3-2006.12 \\
\hline Switzerland & SWI & Monthly & 1960.3-2006.12 & 1960.3-2006.12 \\
\hline United Kingdom & UKG & Monthly & $1960.3-2006.12$ & $1960.3-2006.12$ \\
\hline \multicolumn{2}{|l|}{ Non-OECD } & & & \\
\hline Burkina Faso & BFA & Monthly & 1960.3-2006.10 & 1960.3-2006.10 \\
\hline Chile & $\mathrm{CHL}$ & Monthly & 1960.3-2006.12 & - \\
\hline Colombia & $\mathrm{COL}$ & Monthly & $1960.3-2006.12$ & $1960.3-2006.12$ \\
\hline Cyprus & CYP & Monthly & 1960.3-2006.12 & - \\
\hline Dominican Republic & DRP & Monthly & $1960.3-2006.5$ & - \\
\hline El Salvador & SLV & Monthly & 1960.3-2006.12 & - \\
\hline Egypt & EGY & Monthly & 1960.3-2006.12 & - \\
\hline Haiti & HTI & Monthly & $1960.3-2006.6$ & $1960.3-2006.6$ \\
\hline Honduras & HND & Monthly & $1960.3-2006.12$ & 1960.3-2006.12 \\
\hline India & IND & Monthly & 1960.3-2006.11 & - \\
\hline Israel & ISR & Monthly & 1960.3-2006.12 & $1960.3-2006.12$ \\
\hline Ivory Coast & IVC & Monthly & $1960.3-2006.8$ & $1960.3-2006.8$ \\
\hline Jamaica & JAM & Monthly & 1960.3-2006.12 & 1960.3-2006.12 \\
\hline Malta & MAL & Monthly & $1960.3-2006.10$ & - \\
\hline Morocco & MOR & Monthly & $1960.3-2006.12$ & 1960.3-2006.12 \\
\hline Philippines & PHI & Monthly & 1960.3-2006.12 & 1960.3-2006.12 \\
\hline South Africa & SOA & Monthly & 1960.3-2006.12 & 1960.3-2006.12 \\
\hline Sri Lanka & SRI & Monthly & $1960.3-2006.12$ & $1960.3-2006.12$ \\
\hline Trinidad and Tobago & TTO & Monthly & 1960.3-2006.10 & 1960.3-2006.10 \\
\hline Venezuela & VEN & Monthly & 1960.3-2006.11 & $1960.3-2006.11$ \\
\hline
\end{tabular}

Notes:

RER: real exchange rate

REER: real effective exchange rate. 


\section{References:}

Andrews, D., 1993. Test for Parameter Instability and Structural Change with Unknown Change Point. Econometrica 61 (4), 821-856.

Andrews, D., Ploberger, W., 1994. Optimal Tests When a Nuisance Parameter is Present Only Under the Alternative. Econometrica 62 (6), 1383-1414.

Bank of England, 1968. Report for the year ended $29^{\text {th }}$ February 1968, Bank of England, London.

Bastourre, D., Carrera, J., 2004. Could the Exchange Rate Regime Reduce Macroeconomic Volatility? Proceedings of the 32th Brazilian Economics Meeting, available at http://www.anpec.org.br/encontro2004/artigos/A04A067.pdf

Baxter, M., Stockman, A., 1989. Business Cycles and the Exchange-Rate Regime: Some International Evidence. Journal of Monetary Economics 23 (3), 377-400.

Camacho, M., 2004. Vector Smooth Transition Regression Models for the US GDP and the Composite Index of Leading Indicators. Journal of Forecasting 23 (3), 173-196.

Carrera, J., Vuletin, G., 2003. The Effects of Exchange Rate Regimes on Real Exchange Rate Volatility. A Dynamic Panel Data Approach. Proceedings of the 32th Brazilian Economics Meeting, available at http://www.anpec.org.br/encontro2003/artigos/C67.pdf

Cooper, R. N., 1999. Exchange Rate Choices. In Little, J. S., Olivei, G. P. (Eds.), Rethinking the International Monetary System, Federal Reserve Bank of Boston, Conference Series 43, pp. 99-123.

Flood, R., Rose, A., 1995. Fixing Exchange Rates: A Virtual Quest for Fundamentals. Journal of Monetary Economics 36 (1), 3-37.

Frankel, J., Rose, A., 1995. Empirical Research on Nominal Exchange Rates. In Grossman, G., Rogoff, K. (Eds.), Handbook of International Economics Vol. 3, New Holland, Amsterdam, pp. 1689-1729.

Goldfajn, I., Valdés, R. O., 1999. The Aftermath of Appreciations. The Quarterly Journal of Economics 114 (1), 229-262.

Grilly, V., Kaminsky, G., 1991. Nominal Exchange Rate Regimes and Real Exchange Rate: Evidence from the United States and Britain, 1885-86. Journal of Monetary Economics 27 (2), 191-212.

Hansen, B.E., 1997. Approximate Asymptotic P Values for Structural-Change Tests. Journal of Business and Economic Statistics 15 (1), 60-67. 
Hausman, R., Gavin, M., Pages, C., Stain, E., 1999. Financial Turmoil and the Crises of Exchange Rate Regimes, Inter-American Development Bank Working Paper No. 400, Washington, D.C.

Kent, C., Naja, R., 1998. Effective Exchange Rates and Irrelevant Nominal ExchangeRate Regime, Reserve Bank of Australia Research Discussion Paper, 9811, Sydney.

Ledesma-Rodríguez, F., Navarro-Ibáñez, M., Pérez-Rodríguez, J., Sosvilla-Rivero, S., 2007. Implicit Bands in the Spanish Peseta/Deutschmark Exchange Rate, 1965-1998. Applied Financial Economics 17 (11), 921-932

Liang, H., 1998. Real Exchange Rate Volatility: Does the Nominal Exchange Rate Regime Matter?. IMF Working Paper, 98147, Washington, D.C.

McConnell, M. M., Pérez-Quirós, G., 2000. Output Fluctuations in the United States: What has Changed Since the Early 1980s? American Economic Review 90 (5), 4641476.

Mussa, M., 1986. Nominal Exchange Rate Regimes and the Behaviour of the Real Exchange Rates: Evidence and Implications. Carnegie-Rochester Conference Series on Public Policy 25 (1), 117-214.

Reinhart, C. M., Rogoff, K. S., 2004. The Modern History of Exchange Rate Arrangements: A Reinterpretation. Quarterly Journal of Economics 119 (1), 1-48.

Rodrik, D., 2000. Exchange Rate Regimes and Institutional Arrangements in the Shadow of Capital Flows. Paper presented on a conference on Central Banking and Sustainable development, held in Kuala Lumpur, Malaysia. Available at http://ksghome.harvard.edu/ drodrik/malaysia\%20conference\%20paper.pdf

Rogers, J. H., 1995. Real Shocks and Real Exchange Rates in Really Long-Term Data. International Finance Discussion Papers, Board of Governors of the Federal Reserve System, 493, Washington, D.C.

Sin, C. Y., White, H., 1996. Information Criteria for Selecting Possibly Misspecified Parametric Models. Journal of Econometrics 71 (1-2), 207-225. 
Table 1. Hansen's (1997) P-values of the Supreme, Exponential and Average Tests

\begin{tabular}{|c|c|c|c|c|c|c|}
\hline OECD RER $^{a}$ & Periods & Pvsup $^{b}$ & Pvexp & Pvave & Instability $^{\mathrm{c}}$ & R\&R Regimes ${ }^{\mathrm{d}}$ \\
\hline $\begin{array}{l}\text { AUSTRALIA } \\
\text { 1963.I- 2003.IV }\end{array}$ & $\begin{array}{l}\text { From 1963.I to 1963.IV } \\
\text { From 1964.I to 1973.III } \\
\text { From 1973.IV to 1976.III } \\
\text { From 1976.IV to 1982.IV } \\
\text { From 1983.I to 2003.IV }\end{array}$ & $\begin{array}{l}<0.05 \\
>0.05 \\
>0.05 \\
>0.05 \\
<0.05\end{array}$ & $\begin{array}{c}<0.05 \\
>0.05 \\
{[0.05,0.10]} \\
<0.05 \\
<0.05\end{array}$ & $\begin{array}{l}<0.05 \\
>0.05 \\
<0.05 \\
<0.05 \\
<0.05\end{array}$ & $\begin{array}{l}\text { YES } \\
\text { NO } \\
\text { YES* } \\
\text { YES } \\
\text { YES }\end{array}$ & $\begin{array}{c}\text { FIXED } \\
\text { FIXED } \\
\text { QUASI-FIXED } \\
\text { QUASI-FLEXIBLE } \\
\text { FREELY FLOATING }\end{array}$ \\
\hline $\begin{array}{c}\text { AUSTRIA } \\
1963.3-1998.12\end{array}$ & $\begin{array}{l}\text { From } 1963.1 \text { to } 1968.6 \\
\text { From } 1968.7 \text { to } 1971.4 \\
\text { From } 1971.5 \text { to } 1974.11 \\
\text { From } 1974.12 \text { to } 1998.12\end{array}$ & $\begin{array}{l}>0.05 \\
<0.05 \\
>0.05 \\
<0.05\end{array}$ & $\begin{array}{l}>0.05 \\
<0.05 \\
>0.05 \\
<0.05\end{array}$ & $\begin{array}{c}>0.05 \\
{[0.05,0.10]} \\
>0.05 \\
<0.05\end{array}$ & $\begin{array}{l}\text { NO } \\
\text { YES } \\
\text { NO } \\
\text { YES }\end{array}$ & $\begin{array}{c}\text { FIXED } \\
\text { FIXED } \\
\text { QUASI-FLEXIBLE } \\
\text { FREELY FLOATING }\end{array}$ \\
\hline $\begin{array}{c}\text { BELGIUM } \\
1963.3-1998.12\end{array}$ & $\begin{array}{l}\text { From } 1963.1 \text { to } 1973.3 \\
\text { From } 1973.4 \text { to } 1974.1 \\
\text { From } 1974.2 \text { to } 1975.6 \\
\text { From } 1975.7 \text { to } 1998.12\end{array}$ & $\begin{array}{l}>0.05 \\
>0.05 \\
>0.05 \\
<0.05\end{array}$ & $\begin{array}{l}>0.05 \\
>0.05 \\
<0.05 \\
<0.05\end{array}$ & $\begin{array}{l}>0.05 \\
<0.05 \\
<0.05 \\
<0.05\end{array}$ & $\begin{array}{l}\text { NO } \\
\text { NO } \\
\text { YES } \\
\text { YES }\end{array}$ & $\begin{array}{c}\text { FIXED } \\
\text { FIXED } \\
\text { FREELY FLOATING } \\
\text { FREELY FLOATING }\end{array}$ \\
\hline $\begin{array}{c}\text { CANADA } \\
1963.3-2006.12\end{array}$ & $\begin{array}{l}\text { From } 1963.3 \text { to } 1978.8 \\
\text { From } 1978.9 \text { to } 1979.5 \\
\text { From } 1979.6 \text { to } 1982.4 \\
\text { From } 1982.5 \text { to } 2006.12\end{array}$ & $\begin{array}{l}>0.05 \\
>0.05 \\
>0.05 \\
<0.05\end{array}$ & $\begin{array}{l}>0.05 \\
>0.05 \\
<0.05 \\
<0.05\end{array}$ & $\begin{array}{l}>0.05 \\
<0.05 \\
<0.05 \\
<0.05\end{array}$ & $\begin{array}{l}\text { NO } \\
\text { NO } \\
\text { YES } \\
\text { YES }\end{array}$ & $\begin{array}{c}\text { FIXED } \\
\text { FIXED } \\
\text { QUASI-FLEXIBLE } \\
\text { QUASI-FLEXIBLE }\end{array}$ \\
\hline $\begin{array}{l}\text { DENMARK } \\
\text { 1963.I-2003.IV }\end{array}$ & $\begin{array}{l}\text { From 1963.I to } 1975 . \mathrm{II} \\
\text { From 1975.III to } 1978 . \mathrm{III} \\
\text { From 1978.IV to 1979.IV } \\
\text { From 1980.I to 2003.IV }\end{array}$ & $\begin{array}{l}>0.05 \\
>0.05 \\
>0.05 \\
<0.05\end{array}$ & $\begin{array}{l}>0.05 \\
{[0.05,0.10]} \\
\quad<0.05 \\
<0.05\end{array}$ & $\begin{array}{l}>0.05 \\
<0.05 \\
<0.05 \\
<0.05\end{array}$ & $\begin{array}{l}\text { NO } \\
\text { YES* } \\
\text { YES } \\
\text { YES }\end{array}$ & $\begin{array}{c}\text { FIXED } \\
\text { QUASI-FLEXIBLE } \\
\text { FREELY FLOATING } \\
\text { FREELY FLOATING }\end{array}$ \\
\hline $\begin{array}{c}\text { FINLAND } \\
\text { 1963.I-1998.IV }\end{array}$ & $\begin{array}{l}\text { From 1963.I to 1963.IV } \\
\text { From 1964.I to 1964.III } \\
\text { From 1964.IV to 1967.III } \\
\text { From 1967.IV to 1969.II } \\
\text { From 1970.IV to 1974.III } \\
\text { From 1974.IV to 1975.III } \\
\text { From 1975.IV to 1979.IV } \\
\text { From 1980.I to 1998.IV }\end{array}$ & $\begin{array}{l}>0.05 \\
>0.05 \\
>0.05 \\
>0.05 \\
>0.05 \\
>0.05 \\
>0.05 \\
<0.05\end{array}$ & $\begin{array}{l}>0.05 \\
<0.05 \\
>0.05 \\
<0.05 \\
>0.05 \\
{[0.05,0.10]} \\
<0.05 \\
<0.05\end{array}$ & $\begin{array}{l}>0.05 \\
<0.05 \\
>0.05 \\
<0.05 \\
>0.05 \\
<0.05 \\
<0.05 \\
<0.05\end{array}$ & $\begin{array}{l}\text { NO } \\
\text { YES } \\
\text { NO } \\
\text { YES } \\
\text { NO } \\
\text { YES* } \\
\text { YES } \\
\text { YES }\end{array}$ & $\begin{array}{c}\text { QUASI-FIXED } \\
\text { QUASI-FIXED } \\
\text { QUASI-FIXED } \\
\text { FIXED } \\
\text { FIXED } \\
\text { FREELY FLOATING } \\
\text { FREELY FLOATING } \\
\text { FREELY FLOATING }\end{array}$ \\
\hline $\begin{array}{c}\text { FRANCE } \\
1963.3-1998.12\end{array}$ & $\begin{array}{l}\text { From } 1963.3 \text { to } 1973.12 \\
\text { From } 1974.1 \text { to } 1975.1 \\
\text { From } 1975.2 \text { to } 1998.12\end{array}$ & $\begin{array}{l}>0.05 \\
>0.05 \\
<0.05\end{array}$ & $\begin{array}{l}>0.05 \\
<0.05 \\
<0.05\end{array}$ & $\begin{array}{l}>0.05 \\
<0.05 \\
<0.05\end{array}$ & $\begin{array}{l}\text { NO } \\
\text { YES } \\
\text { YES }\end{array}$ & $\begin{array}{c}\text { FIXED } \\
\text { FREELY FLOATING } \\
\text { FREELY FLOATING }\end{array}$ \\
\hline $\begin{array}{c}\text { GERMANY } \\
1963.3-1998.12\end{array}$ & $\begin{array}{l}\text { From } 1963.3 \text { to } 1973.2 \\
\text { From } 1973.3 \text { to } 1975.9 \\
\text { From } 1975.10 \text { to } 1998.12\end{array}$ & $\begin{array}{l}>0.05 \\
>0.05 \\
<0.05\end{array}$ & $\begin{array}{l}>0.05 \\
<0.05 \\
<0.05\end{array}$ & $\begin{array}{l}>0.05 \\
<0.05 \\
<0.05\end{array}$ & $\begin{array}{l}\text { NO } \\
\text { YES } \\
\text { YES }\end{array}$ & $\begin{array}{c}\text { FIXED } \\
\text { FREELY FLOATING } \\
\text { FREELY FLOATING }\end{array}$ \\
\hline $\begin{array}{c}\text { GREECE } \\
\text { 1963.3-1998.12 }\end{array}$ & $\begin{array}{l}\text { From } 1963.3 \text { to } 1972.6 \\
\text { From } 1972.7 \text { to } 1974.3 \\
\text { From } 1974.4 \text { to } 1977.9 \\
\text { From } 1977.10 \text { to } 1998.12\end{array}$ & $\begin{array}{l}>0.05 \\
>0.05 \\
>0.05 \\
<0.05\end{array}$ & $\begin{array}{l}>0.05 \\
>0.05 \\
<0.05 \\
<0.05\end{array}$ & $\begin{array}{l}>0.05 \\
{[0.05,0.10]} \\
\quad<0.05 \\
<0.05\end{array}$ & $\begin{array}{l}\text { NO } \\
\text { NO } \\
\text { YES } \\
\text { YES }\end{array}$ & $\begin{array}{c}\text { FIXED } \\
\text { FIXED } \\
\text { FREELY FLOATING } \\
\text { FREELY FLOATING }\end{array}$ \\
\hline $\begin{array}{c}\text { IRELAND } \\
\text { 1963.I-1998.IV }\end{array}$ & $\begin{array}{l}\text { From 1963.I to } 1973 . I I I \\
\text { From 1973.IV to 1976.I } \\
\text { From 1976.II to 1976.IV } \\
\text { From 1977.I to 1979.IV } \\
\text { From 1980.I to 1981.II } \\
\text { From 1981.III to 1998.IV }\end{array}$ & $\begin{array}{l}>0.05 \\
>0.05 \\
>0.05 \\
>0.05 \\
>0.05 \\
<0.05\end{array}$ & $\begin{aligned} &>0.05 \\
&>0.05 \\
&<0.05 \\
& {[0.05,0.10] } \\
& \quad<0.05 \\
&<0.05\end{aligned}$ & $\begin{array}{l}>0.05 \\
<0.05 \\
<0.05 \\
<0.05 \\
<0.05 \\
<0.05\end{array}$ & $\begin{array}{l}\text { NO } \\
\text { NO } \\
\text { YES } \\
\text { YES* } \\
\text { YES } \\
\text { YES }\end{array}$ & $\begin{array}{l}\text { QUASI-FLEXIBLE } \\
\text { QUASI-FLEXIBLE } \\
\text { QUASI-FLEXIBLE } \\
\text { QUASI-FLEXIBLE } \\
\text { FREELY FLOATING } \\
\text { FREELY FLOATING }\end{array}$ \\
\hline
\end{tabular}

Notes: a. RER: real exchange rate; b. Pvsup, Pvexp and Pvave are the p-values of the supreme test developed by Andrews (1993) and the exponential and average tests developed by Andrews and Ploberger (1994); c. YES: evidence of instability in the variance of the real exchange rate at 5\% significant level, YES*: evidence of instability in the variance of the real exchange rate at $10 \%$ significant level, NO: no evidence of instability in the variance of the real exchange rate at $5 \%$ significant level. d. Reinhart and Rogoff (2004)'s coarse grid classification. 
Table 1 (cont.). Hansen's (1997) P-values of the Supreme, Exponential and Average Tests

\begin{tabular}{|c|c|c|c|c|c|c|}
\hline OECD RER $^{\mathrm{a}}$ & Periods & Pvsup $^{b}$ & Pvexp & Pvave & Instability $^{\mathrm{c}}$ & R\&R Regimes ${ }^{\mathrm{d}}$ \\
\hline ITALY & From 1963.3 to 1975.6 & $>0.05$ & $>0.05$ & $>0.05$ & NO & FIXED \\
\hline \multirow[t]{3}{*}{ 1963.3-1998.12 } & From 1975.7 to 1975.10 & $>0.05$ & {$[0.05,0.10]$} & $<0.05$ & YES* & QUASI-FIXED \\
\hline & From 1975.11 to 1978.10 & $>0.05$ & $<0.05$ & $<0.05$ & YES & QUASI-FLEXIBLE \\
\hline & From 1978.11 to 1998.12 & $<0.05$ & $<0.05$ & $<0.05$ & YES & FREELY FLOATING \\
\hline \multirow{4}{*}{$\begin{array}{c}\text { JAPAN } \\
1963.3-2006.12\end{array}$} & From 1963.3 to 1974.1 & $>0.05$ & $>0.05$ & $>0.05$ & NO & FIXED \\
\hline & From 1974.2 to 1974.9 & $>0.05$ & $>0.05$ & $<0.05$ & NO & QUASI-FIXED \\
\hline & From 1974.10 to 1978.2 & $>0.05$ & $<0.05$ & $<0.05$ & YES & FREELY FLOATING \\
\hline & From 1978.3 to 2006.12 & $<0.05$ & $<0.05$ & $<0.05$ & YES & FREELY FLOATING \\
\hline \multirow{11}{*}{$\begin{array}{c}\text { KOREA } \\
1963.3-2006.12\end{array}$} & From 1963.3 to 1964.4 & $>0.05$ & $>0.05$ & $>0.05$ & NO & QUASI-FIXED \\
\hline & From 1964.5 to 1964.12 & $<0.05$ & $<0.05$ & $>0.05$ & YES & QUASI-FLEXIBLE \\
\hline & From 1965.1 to 1966.4 & $>0.05$ & $>0.05$ & $>0.05$ & NO & QUASI-FLEXIBLE \\
\hline & From 1965.5 to 1966.12 & $>0.05$ & $<0.05$ & $>0.05$ & NO & QUASI-FLEXIBLE \\
\hline & From 1967.1 to 1968.6 & $>0.05$ & $<0.05$ & $<0.05$ & YES & QUASI-FLEXIBLE \\
\hline & From 1968.7 to 1969.11 & $<0.05$ & $<0.05$ & $<0.05$ & YES & QUASI-FLEXIBLE \\
\hline & From 1969.12 to 1973.8 & $>0.05$ & $<0.05$ & $<0.05$ & YES & QUASI-FLEXIBLE \\
\hline & From 1973.9 to 1974.11 & $<0.05$ & $<0.05$ & $<0.05$ & YES & FIXED \\
\hline & From 1974.12 to 1977.8 & $>0.05$ & $<0.05$ & $<0.05$ & YES & FIXED \\
\hline & From 1977.9 to 2005.8 & $<0.05$ & $<0.05$ & $<0.05$ & YES & QUASI-FLEXIBLE \\
\hline & From 2005.9 to 2006.12 & $>0.05$ & $<0.05$ & $<0.05$ & YES & FREELY FLOATING \\
\hline \multirow{6}{*}{$\begin{array}{l}\text { LUXEMBURG } \\
\text { 1963.I-1998.IV }\end{array}$} & From 1963.I to 1971.II & $>0.05$ & $>0.05$ & $>0.05$ & NO & FIXED \\
\hline & From 1971.III to 1971.IV & $>0.05$ & $>0.05$ & $<0.05$ & NO & QUASI-FIXED \\
\hline & From 1972.I to 1973.I & $>0.05$ & $<0.05$ & $<0.05$ & YES & QUASI-FLEXIBLE \\
\hline & From 1973.II to 1974.II & $>0.05$ & {$[0.05,0.10]$} & $<0.05$ & YES* & QUASI-FLEXIBLE \\
\hline & From 1974. III to 1975. II & $>0.05$ & $<0.05$ & $<0.05$ & YES & FREELY FLOATING \\
\hline & From 1975.III to 1998.IV & $<0.05$ & $<0.05$ & $<0.05$ & YES & FREELY FLOATING \\
\hline \multirow{7}{*}{$\begin{array}{c}\text { NETHERLANDS } \\
1963.3-1998.12\end{array}$} & From 1963.3 to 1967.8 & $>0.05$ & $>0.05$ & $>0.05$ & NO & FIXED \\
\hline & From 1967.9 to 1967.10 & $>0.05$ & $>0.05$ & $<0.05$ & NO & FIXED \\
\hline & From 1967.11 to 1968.6 & $>0.05$ & $<0.05$ & $<0.05$ & YES & FIXED \\
\hline & From 1968.7 to 1968.12 & $>0.05$ & $>0.05$ & $<0.05$ & NO & FIXED \\
\hline & From 1969.1 to 1975.1 & $>0.05$ & $>0.05$ & $>0.05$ & NO & FIXED \\
\hline & From 1975.2 to 1975.9 & $>0.05$ & $<0.05$ & $<0.05$ & YES & FREELY FLOATING \\
\hline & From 1975.10 to 1998.12 & $<0.05$ & $<0.05$ & $<0.05$ & YES & FREELY FLOATING \\
\hline \multirow{10}{*}{$\begin{array}{l}\text { NEW ZEALAND } \\
\text { 1963.I-2003.IV }\end{array}$} & From 1963.I to 1967.II & $>0.05$ & $>0.05$ & $>0.05$ & & FIXED \\
\hline & From 1967.III to 1967.IV & $<0.05$ & $<0.05$ & $<0.05$ & YES & QUASI-FIXED \\
\hline & From 1968.I to 1968.IV & $>0.05$ & $<0.05$ & $<0.05$ & YES & QUASI-FIXED \\
\hline & From 1969.I to 1969. III & $<0.05$ & $<0.05$ & $<0.05$ & YES & QUASI-FIXED \\
\hline & From 1969.IV to $1972 . \mathrm{I}$ & $>0.05$ & $<0.05$ & $<0.05$ & YES & FIXED \\
\hline & From 1972.II to 1972.IV & $>0.05$ & {$[0.05,0.10]$} & $<0.05$ & YES* & FIXED \\
\hline & From 1973.I to $1975 . I I$ & $>0.05$ & $>0.05$ & $>0.05$ & NO & FIXED \\
\hline & From 1975.III to 1976.I & $>0.05$ & {$[0.05,0.10]$} & $<0.05$ & YES* & QUASI-FLEXIBLE \\
\hline & From 1976.II to 1983.IV & $>0.05$ & $<0.05$ & $<0.05$ & YES & QUASI-FLEXIBLE \\
\hline & From 1984.I to 2003.IV & $<0.05$ & $<0.05$ & $<0.05$ & YES & FREELY FLOATING \\
\hline \multirow{4}{*}{$\begin{array}{c}\text { NORWAY } \\
1963.3-2006.12\end{array}$} & From 1963.3 to 1963.4 & $<0.05$ & $<0.05$ & $>0.05$ & YES & FIXED \\
\hline & From 1963.5 to 1973.5 & $>0.05$ & $>0.05$ & $>0.05$ & NO & FIXED \\
\hline & From 1973.6 to 1976.12 & $>0.05$ & $<0.05$ & $<0.05$ & YES & FREELY FLOATING \\
\hline & From 1977.1 to 2006.12 & $<0.05$ & $<0.05$ & $<0.05$ & YES & FREELY FLOATING \\
\hline
\end{tabular}

Notes: a. RER: real exchange rate; b. Pvsup, Pvexp and Pvave are the p-values of the supreme test developed by Andrews (1993) and the exponential and average tests developed by Andrews and Ploberger (1994). c. YES: evidence of instability in the variance of the real exchange rate at 5\% significant level, YES*: evidence of instability in the variance of the real exchange rate at $10 \%$ significant level, NO: no evidence of instability in the variance of the real exchange rate at $5 \%$ significant level. d. Reinhart and Rogoff (2004)'s coarse grid classification. 
Table 1 (cont.). Hansen's (1997) P-values of the Supreme, Exponential and Average Tests

\begin{tabular}{|c|c|c|c|c|c|c|}
\hline OECD RER $^{\mathrm{a}}$ & Periods & Pvsup $^{b}$ & Pvexp & Pvave & Instability $^{\mathrm{c}}$ & R\&R Regimes ${ }^{d}$ \\
\hline PORTUGAL & From 1963.I to 1973.IV & $>0.05$ & $>0.05$ & $>0.05$ & $\mathrm{NO}$ & FIXED \\
\hline \multirow{3}{*}{ 1963.I-1998.IV } & From 1974.I to 1976.IV & $>0.05$ & {$[0.05,0.10]$} & $<0.05$ & YES* & QUASI-FLEXIBLE \\
\hline & From 1977.I to 1981.I & $>0.05$ & $<0.05$ & $<0.05$ & YES & FREELY FLOATING \\
\hline & From 1981.II to 1998.IV & $<0.05$ & $<0.05$ & $<0.05$ & YES & FREELY FLOATING \\
\hline & From 1963.3 to 1981.3 & $>0.05$ & $>0.05$ & $>0.05$ & NO & FIXED \\
\hline \multirow{3}{*}{ 1963.3-1998.12 } & From 1981.4 to 1982.5 & $<0.05$ & {$[0.05,0.10]$} & $<0.05$ & YES* & QUSI-FIXED \\
\hline & From 1982.6 to 1987.7 & $>0.05$ & $<0.05$ & $<0.05$ & YES & FREELY FLOATING \\
\hline & From 1987.7 to 1998.12 & $<0.05$ & $<0.05$ & $<0.05$ & YES & FREELY FLOATING \\
\hline SWEDEN & From 1963.3 to 1969.7 & $>0.05$ & $>0.05$ & $>0.05$ & $\mathrm{NO}$ & FIXED \\
\hline \multirow[t]{3}{*}{$1963.3-2006.12$} & From 1969.8 to 1970.1 & $>0.05$ & $<0.05$ & $>0.05$ & NO & FIXED \\
\hline & From 1970.2 to 1974.1 & $<0.05$ & $<0.05$ & $>0.05$ & YES & QUASI-FLEXIBLE \\
\hline & From 1974.2 to 2006.12 & $<0.05$ & $<0.05$ & $<0.05$ & YES & FREELY FLOATING \\
\hline \multirow{3}{*}{$\begin{array}{c}\text { SWITZERLAND } \\
1963.3-2006.12\end{array}$} & From 1963.3 to 1972.4 & $>0.05$ & $>0.05$ & $>0.05$ & NO & FIXED \\
\hline & From 1972.5 to 1975.1 & $>0.05$ & $<0.05$ & $<0.05$ & YES & QUASI-FLEXIBLE \\
\hline & From 1975.2 to 2006.12 & $<0.05$ & $<0.05$ & $<0.05$ & YES & FREELY FLOATING \\
\hline UNITED & From 1963.3 to 1972.8 & $>0.05$ & $>0.05$ & $>0.05$ & NO & FIXED \\
\hline KINGDOM & From 1972.9 to 1973.8 & $>0.05$ & $>0.05$ & $<0.05$ & NO & QUASI-FLEXIBLE \\
\hline \multirow{2}{*}{$1963.3-2006.12$} & From 1973.9 to 1975.6 & $>0.05$ & $<0.05$ & $<0.05$ & YES & QUASI-FLEXIBLE \\
\hline & From 1975.7 to 2006.12 & $<0.0 \mathrm{~S}$ & $<0.05$ & $<0.05$ & YES & FREELY FLOATING \\
\hline
\end{tabular}

Notes

RER: real exchange rate.

b. Pvsup, Pvexp and Pvave are the p-values of the supreme test developed by Andrews (1993) and the exponential and average tests developed by Andrews and Ploberger (1994).

c. YES: evidence of instability in the variance of the real exchange rate at 5\% significant level, YES*: evidence of instability in the variance of the real exchange rate at $10 \%$ significant level, NO: no evidence

of instability in the variance of the real exchange rate at $5 \%$ significant level.

d. Reinhart and Rogoff (2004)'s coarse grid classification. 
Table 2. Hansen's (1997) P-values of the Supreme, Exponential and Average Tests

\begin{tabular}{|c|c|c|c|c|c|c|}
\hline NON-OECD RER $^{\mathrm{a}}$ & Periods & Pvsup $^{b}$ & Pvexp & Pvave & Instability $^{\mathrm{c}}$ & R\&R Regimes ${ }^{d}$ \\
\hline $\begin{array}{l}\text { BURKINA FASO } \\
1963.3-2006.10\end{array}$ & $\begin{array}{l}\text { From } 1963.3 \text { to } 1973.3 \\
\text { From } 1973.4 \text { to } 1973.8 \\
\text { From } 1973.9 \text { to } 1975.6 \\
\text { From } 1975.7 \text { to } 2006.12\end{array}$ & $\begin{array}{l}>0.05 \\
>0.05 \\
>0.05 \\
<0.05\end{array}$ & $\begin{array}{l}>0.05 \\
>0.05 \\
<0.05 \\
<0.05\end{array}$ & $\begin{array}{l}>0.05 \\
<0.5 \\
<0.05 \\
<0.05\end{array}$ & $\begin{array}{l}\text { NO } \\
\text { NO } \\
\text { YES } \\
\text { YES }\end{array}$ & $\begin{array}{c}\text { FIXED } \\
\text { QUASI-FIXED } \\
\text { FREELY FLOATING } \\
\text { FREELY FLOATING }\end{array}$ \\
\hline $\begin{array}{c}\text { CHILE } \\
1963.3-2006.12\end{array}$ & $\begin{array}{l}\text { From } 1963.3 \\
\text { From 1963.4 to } 1978.4 \\
\text { From 1978.5 to } 1979.1 \\
\text { From } 1979.2 \text { to } 2006.12\end{array}$ & $\begin{array}{l}>0.05 \\
<0.05 \\
>0.05 \\
<0.05\end{array}$ & $\begin{array}{l}>0.05 \\
<0.05 \\
<0.05 \\
<0.05\end{array}$ & $\begin{array}{l}>0.05 \\
<0.05 \\
>0.05 \\
<0.05\end{array}$ & $\begin{array}{l}\text { NO } \\
\text { YES } \\
\text { YES } \\
\text { YES }\end{array}$ & $\begin{array}{l}\text { QUASI-FLEXIBLE } \\
\text { FREELY FALLING } \\
\text { QUASI-FLEXIBLE } \\
\text { QUASI-FLEXIBLE }\end{array}$ \\
\hline $\begin{array}{c}\text { COLOMBIA } \\
1963.3-2006.12\end{array}$ & $\begin{array}{l}\text { From } 1963.3 \text { to } 1963.8 \\
\text { From } 1963.9 \text { to } 1964.3 \\
\text { From } 1964.4 \text { to } 1965.8 \\
\text { From } 1965.9 \text { to } 1967.3 \\
\text { From } 1967.4 \text { to } 1967.7 \\
1967.8 \\
\text { From } 1967.9 \text { to } 1967.11 \\
\text { From } 1967.12 \text { to } 1968.8 \\
\text { From } 1968.9 \text { to } 1968.10 \\
\text { From } 1968.11 \text { to } 1970.8 \\
\text { From } 1970.9 \text { to } 1971.11 \\
1971.12 \\
\text { From } 1972.1 \text { to } 1972.6 \\
\text { From } 1972.7 \text { to } 1973.2 \\
\text { From } 1973.3 \text { to } 1973.9 \\
\text { From } 1973.10 \text { to } 1974.6 \\
\text { From } 1974.7 \text { to } 1974.9 \\
\text { From } 1974.10 \text { to } 1975.1 \\
\text { From } 1975.2 \text { to } 1975.5 \\
\text { From } 1975.6 \text { to } 1975.11 \\
1975.12 \\
\text { From } 1976.1 \text { to } 1976.2 \\
\text { From } 1976.3 \text { to } 1976.5 \\
\text { From } 1976.6 \text { to } 2006.12\end{array}$ & $\begin{array}{l}<0.05 \\
>0.05 \\
>0.05 \\
<0.05 \\
<0.05 \\
>0.05 \\
<0.05 \\
>0.05 \\
<0.05 \\
>0.05 \\
<0.05 \\
>0.05 \\
<0.05 \\
>0.05 \\
<0.05 \\
>0.05 \\
<0.05 \\
>0.05 \\
<0.05 \\
>0.05 \\
<0.05 \\
>0.05 \\
<0.05 \\
>0.05\end{array}$ & $\begin{array}{l}<0.05 \\
>0.05 \\
<0.05 \\
<0.05 \\
<0.05 \\
>0.05 \\
<0.05 \\
>0.05 \\
<0.05 \\
>0.05 \\
<0.05 \\
>0.05 \\
<0.05 \\
>0.05 \\
<0.05 \\
>0.05 \\
<0.05 \\
>0.05 \\
<0.05 \\
>0.05 \\
<0.05 \\
>0.05 \\
<0.05 \\
>0.05\end{array}$ & $\begin{array}{l}<0.05 \\
>0.05 \\
<0.05 \\
<0.05 \\
>0.05 \\
>0.05 \\
>0.05 \\
>0.05 \\
>0.05 \\
>0.05 \\
>0.05 \\
>0.05 \\
>0.05 \\
>0.05 \\
>0.05 \\
>0.05 \\
>0.05 \\
>0.05 \\
>0.05 \\
>0.05 \\
>0.05 \\
>0.05 \\
>0.05 \\
>0.05\end{array}$ & $\begin{array}{l}\text { YES } \\
\text { NO } \\
\text { YES } \\
\text { NO } \\
\text { YES } \\
\text { NO } \\
\text { YES } \\
\text { NO } \\
\text { YES } \\
\text { NO } \\
\text { YES } \\
\text { NO } \\
\text { YES } \\
\text { NO } \\
\text { YES } \\
\text { NO } \\
\text { YES } \\
\text { NO } \\
\text { YES } \\
\text { NO } \\
\text { YES } \\
\text { NO } \\
\text { YES } \\
\text { NO }\end{array}$ & $\begin{array}{l}\text { FREELY FALLING } \\
\text { QUASI-FIXED } \\
\text { QUASI-FLEXIBLE } \\
\text { QUASI-FIXED } \\
\text { QUASI-FLEXIBLE } \\
\text { QUASI-FIXED } \\
\text { QUASI-FIXED } \\
\text { QUASI-FIXED } \\
\text { QUASI-FIXED } \\
\text { QUASIFIXED } \\
\text { QUASI-FIXED } \\
\text { QUASI-FIXED } \\
\text { QUASI-FIXED } \\
\text { QUASI-FIXED } \\
\text { QUASI-FIXED } \\
\text { QUASI-FIXED } \\
\text { QUASI-FIXED } \\
\text { QUASI-FIXED } \\
\text { QUASI-FIXED } \\
\text { QUASIFIXED } \\
\text { QUASI-FIXED } \\
\text { QUASI-FIXED } \\
\text { QUASI-FLEXIBLE } \\
\text { QUASI-FLEXIBLE }\end{array}$ \\
\hline $\begin{array}{c}\text { CYPRUS } \\
1963.3-2006.12\end{array}$ & $\begin{array}{l}\text { From } 1963.3 \text { to } 1981.4 \\
\text { From } 1981.5 \text { to } 1981.7 \\
\text { From } 1981.8 \text { to } 1983.10 \\
\text { From } 1983.11 \text { to } 2006.12\end{array}$ & $\begin{array}{l}>0.05 \\
>0.05 \\
>0.05 \\
<0.05\end{array}$ & $\begin{array}{l}>0.05 \\
<0.05 \\
<0.05 \\
<0.05\end{array}$ & $\begin{array}{l}>0.05 \\
>0.05 \\
<0.05 \\
<0.05\end{array}$ & $\begin{array}{l}\text { NO } \\
\text { NO } \\
\text { YES } \\
\text { YES }\end{array}$ & $\begin{array}{c}\text { FIXED } \\
\text { FIXED } \\
\text { FREELY FLOATING } \\
\text { FREELY FLOATING }\end{array}$ \\
\hline $\begin{array}{c}\text { DOMINICAN REPUBLIC } \\
\text { 1963.3-2006.12 }\end{array}$ & $\begin{array}{l}\text { From } 1963.3 \text { to } 1976.6 \\
\text { From } 1976.7 \text { to } 1975.11 \\
\text { From } 1976.12 \text { to } 1977.10 \\
\text { From } 1977.11 \text { to } 1978.2 \\
\text { From } 1978.3 \text { to } 1978.8 \\
\text { From } 1978.9 \text { to } 1979.11 \\
\text { From } 1979.12 \text { to } 1981.12 \\
\text { From } 1982.1 \text { to } 1983.3 \\
\text { From } 1983.9 \text { to } 1984.12 \\
\text { From } 1985.1 \text { to } 1987.8 \\
\text { From } 1987.9 \text { to } 1993.1 \\
\text { From } 1993.2 \text { to } 1993.8 \\
\text { From } 1993.9 \text { to } 1996.9 \\
\text { From } 1997.10 \text { to } 1999.3 \\
\text { From } 1999.4 \text { to } 2003.9 \\
\text { From } 2003.10 \text { to } 2006.5\end{array}$ & $\begin{array}{l}>0.05 \\
>0.05 \\
>0.05 \\
>0.05 \\
>0.05 \\
>0.05 \\
>0.05 \\
>0.05 \\
<0.05 \\
>0.05 \\
<0.05 \\
>0.05 \\
>0.05 \\
<0.05 \\
<0.05 \\
>0.05\end{array}$ & $\begin{array}{l}>0.05 \\
{[0.05,0.10]} \\
>0.05 \\
{[0.05,0.10]} \\
>0.05 \\
{[0.05,0.10]} \\
>0.05 \\
<0.05 \\
<0.05 \\
>0.05 \\
<0.05 \\
<0.05 \\
>0.05 \\
<0.05 \\
<0.05 \\
>0.05\end{array}$ & $\begin{array}{l}<0.05 \\
{[0.05,0.10]} \\
>0.05 \\
{[0.05,0.10]} \\
>0.05 \\
{[0.05,0.10]} \\
>0.05 \\
<0.05 \\
<0.05 \\
>0.05 \\
<0.05 \\
>0.05 \\
>0.05 \\
>0.05 \\
<0.05 \\
>0.05\end{array}$ & $\begin{array}{c}\text { NO } \\
\text { YES* } \\
\text { NO } \\
\text { YES* } \\
\text { NO } \\
\text { YES* } \\
\text { NO } \\
\text { YES } \\
\text { YES } \\
\text { NO } \\
\text { YES } \\
\text { NO } \\
\text { NO } \\
\text { YES } \\
\text { YES } \\
\text { NO }\end{array}$ & $\begin{array}{c}\text { QUASI-FIXED } \\
\text { QUASI-FIXED } \\
\text { QUASI-FIXED } \\
\text { QUASI-FIXED } \\
\text { QUASI-FIXED } \\
\text { QUASI-FIXED } \\
\text { QUASI-FIXED } \\
\text { QUASI-FLEXIBLE } \\
\text { QUASI-FLEXIBLE } \\
\text { QUASI-FIXED } \\
\text { FREELY FALLING } \\
\text { QUASI-FIXED } \\
\text { QUASI-FIXED } \\
\text { QUASI-FIXED } \\
\text { QUASI-FIXED } \\
\text { N/A }\end{array}$ \\
\hline
\end{tabular}

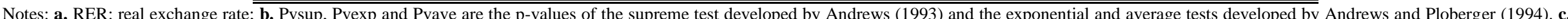
YES: evidence of instability in the variance of the real exchange rate at $5 \%$ significant level, YES*: evidence of instability in the variance of the real exchange rate at $10 \%$ significant level, NO: no evidence of instability in the variance of the real exchange rate at $5 \%$ significant level. d. Reinhart and Rogoff (2004)'s coarse grid classification. N/A= no available 
Table 2 (cont.). Hansen's (1997) P-values of the Supreme, Exponential and Average Tests

\begin{tabular}{|c|c|c|c|c|c|c|}
\hline $\begin{array}{c}\text { NON-OECD } \\
\text { RER }^{a}\end{array}$ & Periods & Pvsup $^{b}$ & Pvexp & Pvave & Instability $^{c}$ & $R \& R$ Regimes ${ }^{d}$ \\
\hline \multirow{4}{*}{$\begin{array}{c}\text { EL SALVADOR } \\
1963.3-2006.12\end{array}$} & From 1963.3 to 1990.4 & $>0.05$ & $>0.05$ & $>0.05$ & NO & FIXED \\
\hline & From 1990.5 to 1991.3 & $<0.05$ & $<0.05$ & $<0.05$ & YES & QUASI-FIXED \\
\hline & From 1991.4 to 2000.4 & $>0.05$ & $<0.05$ & $<0.05$ & YES & FREELY FLOATING \\
\hline & From 2000.5 to 2006.12 & $<0.05$ & $<0.05$ & $<0.05$ & YES & FREELY FLOATING \\
\hline \multirow{8}{*}{$\begin{array}{c}\text { EGYPT } \\
\text { 1963.I-1998.IV }\end{array}$} & From 1963.3 to 1963.9 & $<0.05$ & $<0.05$ & $<0.05$ & YES & QUASI-FLEXIBLE \\
\hline & From 1963.10 to 1963.12 & $>0.05$ & $>0.05$ & $<0.05$ & NO & QUASI-FLEXIBLE \\
\hline & From 1964.1 to 1964.11 & $<0.05$ & $<0.05$ & $<0.05$ & YES & QUASI-FLEXIBLE \\
\hline & From 1964.12 to 1982.3 & $>0.05$ & $>0.05$ & $>0.05$ & NO & QUASI-FLEXIBLE \\
\hline & From 1982.4 to 1982.6 & $>0.05$ & $<0.05$ & $<0.05$ & YES & QUASI-FLEXIBLE \\
\hline & From 1982.7 to 1985.5 & $>0.05$ & $>0.05$ & $<0.05$ & NO & QUASI-FLEXIBLE \\
\hline & From 1985.6 to 1989.7 & $>0.05$ & $<0.05$ & $<0.05$ & YES & QUASI-FLEXIBLE \\
\hline & From 1989.8 to 2006.12 & $<0.05$ & $<0.05$ & $<0.05$ & YES & QUASI-FIXED \\
\hline \multirow{3}{*}{$\begin{array}{c}\text { HAITI } \\
1963.3-2006.6\end{array}$} & From 1963.3 to 1984.3 & $>0.05$ & $>0.05$ & $>0.05$ & & FIXED \\
\hline & From 1984.4 to 1991.8 & $<0.05$ & $<0.05$ & $<0.05$ & YES & FREELY FALLING \\
\hline & From 1991.9 to 2006.6 & $>0.05$ & $>0.05$ & $>0.05$ & NO & QUASI-FIXED \\
\hline \multirow{8}{*}{$\begin{array}{c}\text { HONDURAS } \\
1963.3-2006.12\end{array}$} & From 1963.3 to 1963.10 & $>0.05$ & $>0.05$ & $>0.05$ & NO & FIXED \\
\hline & From 1963.11 to 1964.5 & $>0.05$ & $<0.05$ & $>0.05$ & NO & FIXED \\
\hline & From 1964.6 to 1965.8 & $>0.05$ & $>0.05$ & $>0.05$ & $\mathrm{NO}$ & FIXED \\
\hline & From 1965.9 to 1967.2 & $<0.05$ & $<0.05$ & $>0.05$ & YES & FIXED \\
\hline & From 1967.3 to 1988.3 & $>0.05$ & $>0.05$ & $>0.05$ & NO & QUASI-FIXED \\
\hline & From 1988.4 to 1989.6 & $<0.05$ & $<0.05$ & {$[0.05,0.10]$} & YES & FREELY FALLING \\
\hline & From 1989.7 to 2006.7 & $>0.05]$ & $>0.05$ & $>0.05$ & NO & QUASI-FIXED \\
\hline & From 2006.8 to 2006.12 & $<0.05$ & $>0.05$ & $>0.05$ & NO & N/A \\
\hline \multirow{3}{*}{$\begin{array}{c}\text { INDIA } \\
1963.3-2006.11\end{array}$} & From 1963.3 to 2006.2 & $>0.05$ & $>0.05$ & $>0.05$ & NO & QUASI-FIXED \\
\hline & From 2006.3 to 2006.9 & $<0.05$ & $>0.05$ & $>0.05$ & $\mathrm{NO}$ & N/A \\
\hline & From 2006.10 to 2006.11 & $>0.05$ & $>0.05$ & $>0.05$ & NO & N/A \\
\hline \multirow{4}{*}{$\begin{array}{c}\text { ISRAEL } \\
1963.3-2006.12\end{array}$} & From 1963.3 to 1965.12 & $<0.05$ & $<0.05$ & $<0.05$ & YES & FIXED \\
\hline & From 1966.1 to 1967.4 & $>0.05$ & $<0.05$ & $<0.05$ & YES & FIXED \\
\hline & From 1967.5 to 1971.3 & $<0.05$ & $<0.05$ & $<0.05$ & YES & FIXED \\
\hline & From 1971.4 to 2006.12 & $>0.05$ & $>0.05$ & $>0.05$ & NO & QUASI-FIXED \\
\hline \multirow{9}{*}{$\begin{array}{c}\text { IVORY COAST } \\
1963.3-2006.8\end{array}$} & From 1963.3 to 1982.6 & $>0.05$ & $>0.05$ & $>0.05$ & NO & N/A \\
\hline & From 1982.7 to 1983.4 & $>0.05$ & {$[0.05,0.10]$} & $<0.05$ & YES* & N/A \\
\hline & From 1983.5 to 1984.2 & $>0.05$ & $>0.05$ & $<0.05$ & $\mathrm{NO}$ & N/A \\
\hline & From 1984.3 to 1984.11 & $>0.05$ & {$[0.05,0.10]$} & $<0.05$ & YES* & N/A \\
\hline & From 1984.12 to 1985.7 & $>0.05$ & $>0.05$ & $>0.05$ & $\mathrm{NO}$ & N/A \\
\hline & From 1985.8 to 1987.5 & $>0.05$ & {$[0.05,0.10]$} & $<0.05$ & YES* & N/A \\
\hline & From 1987.6 to 1994.1 & $>0.05$ & $>0.05$ & $>0.05$ & $\mathrm{NO}$ & N/A \\
\hline & From 1994.2 to 1996.7 & $>0.05$ & {$[0.05,0.10]$} & $<0.05$ & YES* & N/A \\
\hline & From 1996.8 to 2006.12 & $>0.05$ & $>0.05$ & $>0.05$ & NO & N/A \\
\hline \multirow{7}{*}{$\begin{array}{l}\text { JAMAICA } \\
1963.3-2006.12\end{array}$} & & $>0.05$ & & $>0.05$ & NO & FIXED \\
\hline & From 1970.2 to 1970.11 & $>0.05$ & $>0.05$ & {$[0.05,0.10]$} & NO & FIXED \\
\hline & From 1970.12 to 1978.4 & $>0.05$ & $>0.05$ & $>0.05$ & $\mathrm{NO}$ & QUASI-FIXED \\
\hline & From 1978.5 to 1980.11 & $>0.05$ & {$[0.05,0.10]$} & $<0.05$ & YES* & FREELY FALLING \\
\hline & From 1980.12 to 1983.12 & $>0.05$ & $>0.05$ & $>0.05$ & NO & FIXED \\
\hline & From 1984.1 to 1985.2 & $>0.05$ & $<0.05$ & $<0.05$ & YES & QUASI-FLEXIBLE \\
\hline & From 1985.3 to 2006.12 & $<0.05$ & $<0.05$ & $<0.05$ & YES & FREELY FLOATING \\
\hline
\end{tabular}

Notes: a. RER: real exchange rate; b. Pvsup, Pvexp and Pvave are the p-values of the supreme test developed by Andrews (1993) and the exponential and average tests developed by Andrews and Ploberger (1994); $\mathbf{c}$ YES: evidence of instability in the variance of the real exchange rate at $5 \%$ significant level, YES*. evidence of instability in the variance of the real exchange rate at $10 \%$ significant level, NO: no evidence of instability in the variance of the real exchange rate at $5 \%$ significant level. d. Reinhart and Rogoff (2004)'s coarse grid classification. N/A= no available 
Table 2 (cont.). Hansen's (1997) P-values of the Supreme, Exponential and Average Tests

\begin{tabular}{|c|c|c|c|c|c|c|}
\hline $\begin{array}{c}\text { NON-OECD } \\
\text { RER }^{\mathrm{a}}\end{array}$ & Periods & Pvsup $^{b}$ & Pvexp & Pvave & Instability $^{c}$ & R\&R Regimes ${ }^{d}$ \\
\hline $\begin{array}{c}\text { MALTA } \\
1963.3-2006.10\end{array}$ & $\begin{array}{l}\text { From } 1963.3 \text { to } 1973.2 \\
\text { From } 1973.3 \text { to } 1973.12 \\
\text { From } 1974.1 \text { to } 1981.1 \\
\text { From } 1981.2 \text { to } 2006.10\end{array}$ & $\begin{array}{l}>0.05 \\
>0.05 \\
>0.05 \\
<0.05\end{array}$ & $\begin{array}{l}>0.05 \\
>0.05 \\
<0.05 \\
<0.05\end{array}$ & $\begin{array}{l}>0.05 \\
<0.05] \\
<0.05 \\
<0.05\end{array}$ & $\begin{array}{l}\text { NO } \\
\text { NO } \\
\text { YES } \\
\text { YES }\end{array}$ & $\begin{array}{c}\text { FIXED } \\
\text { FIXED } \\
\text { QUASI-FLEXIBLE } \\
\text { FREELY FLOATING }\end{array}$ \\
\hline $\begin{array}{c}\text { MOROCCO } \\
1963.3-2006.12\end{array}$ & $\begin{array}{l}\text { From } 1963.3 \text { to } 1974.5 \\
\text { From } 1974.6 \text { to } 1978.12 \\
\text { From } 1979.1 \text { to } 1981.6 \\
\text { From } 1981.7 \text { to } 2006.12\end{array}$ & $\begin{array}{l}>0.05 \\
>0.05 \\
>0.05 \\
<0.05\end{array}$ & $\begin{array}{l}>0.05 \\
>0.05 \\
<0.05 \\
<0.05\end{array}$ & $\begin{array}{l}>0.05 \\
<0.05 \\
<0.05 \\
<0.05\end{array}$ & $\begin{array}{l}\text { NO } \\
\text { NO } \\
\text { YES } \\
\text { YES }\end{array}$ & $\begin{array}{c}\text { FIXED } \\
\text { QUASI-FIXED } \\
\text { FREELY FLOATING } \\
\text { FREELY FLOATING }\end{array}$ \\
\hline $\begin{array}{l}\text { PHILIPPINES } \\
1963.3-2006.12\end{array}$ & $\begin{array}{l}\text { From } 1963.3 \text { to } 1969.4 \\
\text { From } 1969.5 \text { to } 1970.1 \\
\text { From } 1970.2 \text { to } 1979.8 \\
\text { From } 1979.9 \text { to } 1979.11 \\
\text { From } 1979.12 \text { to } 1983.9 \\
\text { From } 1983.10 \text { to } 1989.7 \\
\text { From } 1989.8 \text { to } 1990.3 \\
\text { From } 1990.4 \text { to } 1990.8 \\
\text { From } 1990.9 \text { to } 1990.10 \\
\text { From } 1990.11 \text { to } 2006.12\end{array}$ & $\begin{array}{l}>0.05 \\
>0.05 \\
>0.05 \\
>0.05 \\
<0.05 \\
>0.05 \\
<0.05 \\
<0.05 \\
<0.05 \\
>0.05\end{array}$ & $\begin{array}{l}>0.05 \\
<0.05 \\
>0.05 \\
<0.05 \\
<0.05 \\
>0.05 \\
>0.05 \\
<0.05 \\
>0.05 \\
>0.05\end{array}$ & $\begin{array}{l}>0.05 \\
<0.05 \\
>0.05 \\
<0.05 \\
<0.05 \\
>0.05 \\
>0.05 \\
>0.05 \\
>0.05 \\
>0.05\end{array}$ & $\begin{array}{l}\text { NO } \\
\text { YES } \\
\text { NO } \\
\text { YES } \\
\text { YES } \\
\text { NO } \\
\text { NO } \\
\text { YES } \\
\text { NO } \\
\text { NO }\end{array}$ & $\begin{array}{c}\text { QUASI-FIXED } \\
\text { QUASI-FIXED } \\
\text { QUASI-FIXED } \\
\text { QUASI-FLEXIBLE } \\
\text { FREELY FALLING } \\
\text { QUASI-FIXED } \\
\text { QUASI-FIXED } \\
\text { QUASI-FIXED } \\
\text { QUASI-FIXED } \\
\text { QUASI-FLEXIBLE }\end{array}$ \\
\hline $\begin{array}{c}\text { SOUTH AFRICA } \\
1963.3-2006.12\end{array}$ & $\begin{array}{l}\text { From } 1963.3 \text { to } 1973.1 \\
\text { From } 1973.2 \text { to } 1974.8 \\
\text { From } 1974.9 \text { to } 2006.12\end{array}$ & $\begin{array}{l}>0.05 \\
>0.05 \\
<0.05\end{array}$ & $\begin{array}{l}>0.05 \\
<0.05 \\
<0.05\end{array}$ & $\begin{array}{l}>0.05 \\
<0.05 \\
<0.05\end{array}$ & $\begin{array}{l}\text { NO } \\
\text { YES } \\
\text { YES }\end{array}$ & $\begin{array}{c}\text { FIXED } \\
\text { QUASI-FLEXIBLE } \\
\text { FREELY FLOATING }\end{array}$ \\
\hline $\begin{array}{c}\text { SRI LANKA } \\
1963.3-2006.10\end{array}$ & $\begin{array}{l}\text { From } 1963.3 \text { to } 1973.7 \\
\text { From } 1973.8 \text { to } 1974.2 \\
\text { From } 1974.3 \text { to } 1989.8 \\
\text { From } 1989.9 \text { to } 2006.10\end{array}$ & $\begin{array}{l}>0.05 \\
>0.05 \\
>0.05 \\
<0.05\end{array}$ & $\begin{array}{l}>0.05 \\
{[0.05,0.10]} \\
<0.05] \\
<0.05\end{array}$ & $\begin{array}{l}>0.05 \\
<0.05 \\
<0.05 \\
<0.05\end{array}$ & $\begin{array}{l}\text { NO } \\
\text { YES* } \\
\text { YES* } \\
\text { YES }\end{array}$ & $\begin{array}{c}\text { QUASI-FIXED } \\
\text { QUASI-FIXED } \\
\text { QUASI-FLEXIBLE } \\
\text { QUASI-FLEXIBE }\end{array}$ \\
\hline $\begin{array}{c}\text { TRINIDAD AND } \\
\text { TOBAGO } \\
\text { 1963.3-2006.12 }\end{array}$ & $\begin{array}{l}\text { From } 1963.3 \text { to } 1974.1 \\
\text { From } 1974.2 \text { to } 1975.6 \\
\text { From } 1975.7 \text { to } 1976.11 \\
\text { From } 1976.12 \text { to } 1980.12 \\
\text { From } 1981.1 \text { to } 1984.5 \\
\text { From 1984.6 to } 1990.12 \\
\text { From 1991.1 to } 1993.4 \\
\text { From 1993.5 to } 1995.7 \\
\text { From 1995.8 to } 1997.3 \\
\text { From 1997.4 to } 1999.6 \\
\text { From } 1999.7 \text { to } 2003.1 \\
\text { From } 2003.2 \text { to } 2006.12\end{array}$ & $\begin{array}{l}>0.05 \\
>0.05 \\
<0.05 \\
>0.05 \\
<0.05 \\
>0.05 \\
>0.05 \\
<0.05 \\
>0.05 \\
>0.05 \\
<0.05 \\
<0.05\end{array}$ & $\begin{array}{l}>0.05 \\
<0.05 \\
<0.05 \\
<0.05 \\
<0.05 \\
<0.05 \\
>0.05 \\
<0.05 \\
<0.05 \\
>0.05 \\
<0.05 \\
<0.05\end{array}$ & $\begin{array}{l}>0.05 \\
<0.05 \\
<0.05 \\
<0.05 \\
<0.05 \\
<0.05 \\
>0.05 \\
>0.05 \\
>0.05 \\
>0.05 \\
>0.05 \\
<0.05\end{array}$ & $\begin{array}{l}\text { NO } \\
\text { YES } \\
\text { YES } \\
\text { YES } \\
\text { YES } \\
\text { YES } \\
\text { NO } \\
\text { YES } \\
\text { NO } \\
\text { NO } \\
\text { YES } \\
\text { YES }\end{array}$ & $\begin{array}{l}\text { N/A } \\
\text { N/A } \\
\text { N/A } \\
\text { N/A } \\
\text { N/A } \\
\text { N/A } \\
\text { N/A } \\
\text { N/A } \\
\text { N/A } \\
\text { N/A } \\
\text { N/A } \\
\text { N/A }\end{array}$ \\
\hline $\begin{array}{c}\text { VENEZUELA } \\
1963.3-2006.11\end{array}$ & $\begin{array}{l}\text { From } 1963.3 \text { to } 1969.2 \\
\text { From } 1969.3 \text { to } 1970.3 \\
\text { From } 1970.4 \text { to } 1972.7 \\
1972.8 \\
\text { From } 1972.9 \text { to } 1973.12 \\
\text { From } 1974.1 \text { to } 1978.6 \\
\text { From } 1978.7 \text { to } 1979.9 \\
\text { From } 1979.10 \text { to } 1985.9 \\
\text { From } 1985.10 \text { to } 1986.9 \\
\text { From } 1986.10 \text { to } 2006.12 \\
\end{array}$ & $\begin{array}{l}>0.05 \\
>0.05 \\
>0.05 \\
<0.05 \\
>0.05 \\
>0.05 \\
>0.05 \\
>0.05 \\
>0.05 \\
<0.05 \\
\end{array}$ & $\begin{array}{l}>0.05 \\
>0.05 \\
<0.05 \\
<0.05 \\
<0.05 \\
>0.05 \\
<0.05 \\
>0.05 \\
<0.05 \\
<0.05 \\
\end{array}$ & $\begin{array}{l}>0.05 \\
<0.05 \\
<0.05 \\
<0.05 \\
<0.05 \\
<0.05 \\
<0.05 \\
<0.05 \\
<0.05 \\
<0.05 \\
\end{array}$ & $\begin{array}{l}\text { NO } \\
\text { NO } \\
\text { YES } \\
\text { YES } \\
\text { YES } \\
\text { NO } \\
\text { YES } \\
\text { NO } \\
\text { YES } \\
\text { YES }\end{array}$ & $\begin{array}{c}\text { FIXED } \\
\text { FIXED } \\
\text { FIXED } \\
\text { FIXED } \\
\text { FIXED } \\
\text { FIXED } \\
\text { FIXED } \\
\text { QUASI-FLEXIBLE } \\
\text { FREELY FALLING } \\
\text { QUASI-FLEXIBLE }\end{array}$ \\
\hline
\end{tabular}

Notes: a. RER: real exchange rate; b. Pvsup, Pvexp and Pvave are the p-values of the supreme test developed by Andrews (1993) and the exponential and average tests developed by Andrews and Ploberger (1994).c. YES: evidence of instability in the variance of the real exchange rate at $5 \%$ significant level, YES*: evidence of instability in the variance of the real exchange rate at $10 \%$ significant level, NO: no evidence of instability in the variance of the real exchange rate at 5\% significant level. d. Reinhart and Rogoff (2004)'s coarse grid classification. N/A= no available 
Table 3. Hansen's (1997) P-values of the Supreme, Exponential and Average Tests

\begin{tabular}{|c|c|c|c|c|c|c|}
\hline OECD REER $^{\mathrm{a}}$ & Periods & Pvsup $^{b}$ & Pvexp & Pvave & Instability $^{\mathrm{c}}$ & R\&R Regimes ${ }^{d}$ \\
\hline $\begin{array}{l}\text { AUSTRALIA } \\
\text { 1963.I- 2003:IV }\end{array}$ & $\begin{array}{l}\text { From 1963.I to } 1973 . \mathrm{II} \\
\text { From 1973.III to } 1978 . \mathrm{IV} \\
\text { From 1979.I to } 1998 . \mathrm{IV}\end{array}$ & $\begin{array}{l}>0.05 \\
>0.05 \\
<0.05\end{array}$ & $\begin{array}{l}>0.05 \\
<0.05 \\
<0.05\end{array}$ & $\begin{array}{l}>0.05 \\
<0.05 \\
<0.05\end{array}$ & $\begin{array}{l}\text { NO } \\
\text { YES } \\
\text { YES }\end{array}$ & $\begin{array}{c}\text { FIXED } \\
\text { QUASI-FLEXIBLE } \\
\text { FREELY FLOATING }\end{array}$ \\
\hline $\begin{array}{l}\text { BELGIUM } \\
\text { 1963.3-1998.3 }\end{array}$ & $\begin{array}{l}\text { From } 1963.3 \text { to } 1973.2 \\
\text { From } 1973.3 \text { to } 1980.3 \\
\text { From } 1980.4 \text { to } 1998.12\end{array}$ & $\begin{array}{l}>0.05 \\
>0.05 \\
<0.05\end{array}$ & $\begin{array}{l}>0.05 \\
<0.05 \\
<0.05\end{array}$ & $\begin{array}{l}>0.05 \\
<0.05 \\
<0.05\end{array}$ & $\begin{array}{l}\text { NO } \\
\text { YES } \\
\text { YES }\end{array}$ & $\begin{array}{l}\text { FIXED } \\
\text { FREELY FLOATING } \\
\text { FREELY FLOATING }\end{array}$ \\
\hline $\begin{array}{c}\text { CANADA } \\
\text { 1963.3-2006.12 }\end{array}$ & $\begin{array}{l}\text { From } 1963.3 \text { to } 1965.2 \\
\text { From } 1965.3 \text { to } 1966.2 \\
\text { From } 1966.3 \text { to } 1978.9 \\
\text { From } 1978.10 \text { to } 1981.7 \\
\text { From } 1981.8 \text { to } 2006.12\end{array}$ & $\begin{array}{l}>0.05 \\
>0.05 \\
>0.05 \\
>0.05 \\
<0.05\end{array}$ & $\begin{array}{l}>0.05 \\
>0.05 \\
>0.05 \\
<0.05 \\
<0.05\end{array}$ & $\begin{array}{l}>0.05 \\
<0.05 \\
>0.05 \\
<0.05 \\
<0.05\end{array}$ & $\begin{array}{l}\text { NO } \\
\text { NO } \\
\text { NO } \\
\text { YES } \\
\text { YES }\end{array}$ & $\begin{array}{c}\text { FIXED } \\
\text { FIXED } \\
\text { QUASI-FIXED } \\
\text { QUASI-FLEXISIBLE } \\
\text { QUASI-FLEXISIBLE }\end{array}$ \\
\hline $\begin{array}{l}\text { DENMARK } \\
\text { 1963.I-1998.IV }\end{array}$ & $\begin{array}{l}\text { From 1963.I to } 1980 . \mathrm{I} \\
\text { From 1980.II to } 1987 . \mathrm{III} \\
\text { From 1987.IV to } 1989 . \mathrm{II} \\
\text { From 1989.III to } 1998 . \mathrm{IV}\end{array}$ & $\begin{array}{l}>0.05 \\
>0.05 \\
>0.05 \\
<0.05\end{array}$ & $\begin{array}{l}>0.05 \\
{[0.05,0.10]} \\
\quad<0.05 \\
<0.05\end{array}$ & $\begin{array}{l}>0.05 \\
<0.05 \\
<0.05 \\
<0.05\end{array}$ & $\begin{array}{l}\text { NO } \\
\text { YES* } \\
\text { YES } \\
\text { YES }\end{array}$ & \begin{tabular}{c}
\multicolumn{1}{c}{ FIXED } \\
FREELY FLOATING \\
FREELY FLOATING \\
FREELY FLOATING
\end{tabular} \\
\hline $\begin{array}{l}\text { FINLAND } \\
\text { 1963.I-1998.IV }\end{array}$ & $\begin{array}{l}\text { From 1963.I to } 1967 . I V \\
\text { From 1968.I to } 1968 \text {.III } \\
\text { From 1968.IV to 1972.IV } \\
\text { From 1973.I to 1985.I } \\
\text { From 1985.II to 1988.III } \\
\text { From 1988.IV to } 1998 . I V\end{array}$ & $\begin{array}{l}>0.05 \\
>0.05 \\
>0.05 \\
>0.05 \\
>0.05 \\
>0.05\end{array}$ & $\begin{array}{c}>0.05 \\
<0.05 \\
{[0.05,0.10]} \\
>0.05 \\
{[0.05,0.10]} \\
<0.05\end{array}$ & $\begin{array}{c}>0.05 \\
<0.05 \\
<0.05 \\
>0.05 \\
{[0.05,0.10]} \\
<0.05\end{array}$ & $\begin{array}{l}\text { NO } \\
\text { YES } \\
\text { YES } \\
\text { NO } \\
\text { YES* } \\
\text { YES }\end{array}$ & $\begin{array}{c}\text { QUASI-FIXED } \\
\text { QUASI-FIXED } \\
\text { FIXED } \\
\text { FREELY FLOATING } \\
\text { FREELY FLOATING } \\
\text { FREELY FLOATING }\end{array}$ \\
\hline $\begin{array}{c}\text { FRANCE } \\
1963.3-1998.12\end{array}$ & $\begin{array}{l}\text { From } 1963.3 \text { to } 1974.2 \\
\text { From } 1974.3 \text { to } 1976.4 \\
\text { From } 1976.5 \text { to } 1998.12\end{array}$ & $\begin{array}{l}>0.05 \\
>0.05 \\
<0.05\end{array}$ & $\begin{array}{l}>0.05 \\
<0.05 \\
<0.05\end{array}$ & $\begin{array}{l}>0.05 \\
<0.05 \\
<0.05\end{array}$ & $\begin{array}{l}\text { NO } \\
\text { YES } \\
\text { YES }\end{array}$ & $\begin{array}{c}\text { FIXED } \\
\text { FREELY FLOATING } \\
\text { FREELY FLOATING }\end{array}$ \\
\hline $\begin{array}{c}\text { GERMANY } \\
1963.3-1998.12\end{array}$ & $\begin{array}{l}\text { From } 1963.3 \text { to } 1974.6 \\
\text { From } 1974.7 \text { to } 1976.8 \\
\text { From } 1976.9 \text { to } 2006.12\end{array}$ & $\begin{array}{l}>0.05 \\
>0.05 \\
<0.05\end{array}$ & $\begin{array}{l}>0.05 \\
<0.05 \\
<0.05\end{array}$ & $\begin{array}{l}>0.05 \\
<0.05 \\
<0.05\end{array}$ & $\begin{array}{l}\text { NO } \\
\text { YES } \\
\text { YES }\end{array}$ & $\begin{array}{l}\text { FIXED } \\
\text { FREELY FLOATING } \\
\text { FREELY FLOATING }\end{array}$ \\
\hline $\begin{array}{c}\text { GREECE } \\
1963.3-1998.12\end{array}$ & $\begin{array}{l}\text { From } 1963.3 \text { to } 1969.12 \\
\text { From } 1970.1 \text { to } 1988.5 \\
\text { From } 1988.6 \text { to } 1998.12\end{array}$ & $\begin{array}{l}>0.05 \\
>0.05 \\
>0.05\end{array}$ & $\begin{array}{l}<0.05 \\
>0.05 \\
<0.05\end{array}$ & $\begin{array}{l}<0.05 \\
>0.05 \\
<0.05\end{array}$ & $\begin{array}{l}\text { YES } \\
\text { NO } \\
\text { YES }\end{array}$ & $\begin{array}{c}\text { FIXED } \\
\text { FREELY FLOATING } \\
\text { FREELY FLOATING }\end{array}$ \\
\hline $\begin{array}{c}\text { IRELAND } \\
\text { 1963.I-1998.IV }\end{array}$ & $\begin{array}{l}\text { From 1963.I to } 1973 . I I \\
\text { From 1973.III to } 1973 . I V \\
\text { From 1974.I to } 1974 . \text { III } \\
\text { From 1974.IV to } 1978 . I V \\
\text { From 1979.I to } 1980 . I V \\
\text { From 1981.I to } 1998 . I V\end{array}$ & $\begin{array}{c}>0.05 \\
>0.05 \\
>0.05 \\
>0.05 \\
{[0.05,0.10]} \\
<0.05\end{array}$ & $\begin{array}{l}\quad>0.05 \\
>0.05 \\
{[0.05,0.10]} \\
<0.05 \\
<0.05 \\
<0.05\end{array}$ & $\begin{array}{l}>0.05 \\
<0.05 \\
<0.05 \\
<0.05 \\
<0.05 \\
<0.05\end{array}$ & $\begin{array}{l}\text { NO } \\
\text { NO } \\
\text { YES* } \\
\text { YES } \\
\text { YES } \\
\text { YES }\end{array}$ & $\begin{array}{l}\text { QUASI-FLEXIBLE } \\
\text { QUASI-FLEXIBLE } \\
\text { QUASI-FLEXIBLE } \\
\text { QUASI-FLEXIBLE } \\
\text { FREELY FLOATING } \\
\text { FREELY FLOATING }\end{array}$ \\
\hline $\begin{array}{c}\text { ITALY } \\
\text { 1963.3-1998.12 }\end{array}$ & $\begin{array}{l}\text { From } 1963.3 \text { to } 1974.2 \\
\text { From } 1974.3 \text { to } 1974.9 \\
\text { From } 1974.10 \text { to } 1980.2 \\
\text { From } 1980.3 \text { to } 1998.12\end{array}$ & $\begin{array}{l}>0.05 \\
>0.05 \\
>0.05 \\
<0.05\end{array}$ & $\begin{array}{l}>0.05 \\
>0.05 \\
<0.05 \\
<0.05\end{array}$ & $\begin{array}{l}>0.05 \\
<0.05 \\
<0.05 \\
<0.05\end{array}$ & $\begin{array}{l}\text { NO } \\
\text { NO } \\
\text { YES } \\
\text { YES }\end{array}$ & $\begin{array}{c}\text { FIXED } \\
\text { FIXED } \\
\text { QUASI-FLEXIBLE } \\
\text { FREELY FLOATING }\end{array}$ \\
\hline $\begin{array}{c}\text { JAPAN } \\
1963.3-2006.12\end{array}$ & $\begin{array}{l}\text { From } 1963.3 \text { to } 1974.1 \\
\text { From } 1974.2 \text { to } 1975.1 \\
\text { From } 1975.2 \text { to } 2006.12\end{array}$ & $\begin{array}{l}>0.05 \\
>0.05 \\
<0.05\end{array}$ & $\begin{array}{l}>0.05 \\
>0.05 \\
<0.05\end{array}$ & $\begin{array}{l}>0.05 \\
<0.05 \\
<0.05\end{array}$ & $\begin{array}{l}\text { NO } \\
\text { NO } \\
\text { YES }\end{array}$ & $\begin{array}{c}\text { FIXED } \\
\text { QUASI-FIXED } \\
\text { FREELY FLOATING }\end{array}$ \\
\hline
\end{tabular}

Notes: a. REER: real effective exchange rate; b. Pvsup, Pvexp and Pvave are the p-values of the supreme test developed by Andrews (1993) and the exponential and average tests developed by Andrews and Ploberger (1994); c. YES: evidence of instability in the variance of the real exchange rate at 5\% significant level, YES*: evidence of instability in the variance of the real exchange rate at 10\% significant level, NO: no evidence of instability in the variance of the real exchange rate at 5\% significant level. d. Reinhart and Rogoff (2004)'s coarse grid classification. 
Table 3 (cont.). Hansen's (1997) P-values of the Supreme, Exponential and Average Tests

\begin{tabular}{|c|c|c|c|c|c|c|}
\hline OECD REER $^{\mathrm{a}}$ & Periods & Pvsup $^{6}$ & Pvexp & Pvave & Instability $^{\mathrm{c}}$ & R\&R Regimes $^{\mathrm{d}}$ \\
\hline \multirow{9}{*}{$\begin{array}{c}\text { KOREA } \\
1963.3-2006.12\end{array}$} & From 1963.3 to 1966.2 & $>0.05$ & $>0.05$ & $>0.05$ & $\mathrm{NO}$ & QUASI-FIXED \\
\hline & From 1966.3 to 1966.12 & $>0.05$ & $<0.05$ & $>0.05$ & NO & QUASI-FLEXIBLE \\
\hline & From 1967.1 to 1968.8 & $>0.05$ & $<0.05$ & $<0.05$ & YES & QUASI-FLEXIBLE \\
\hline & From 1968.9 to 1969.10 & $<0.05$ & $<0.05$ & $<0.05$ & YES & QUASI-FLEXIBLE \\
\hline & From 1969.11 to 1973.8 & $>0.05$ & $<0.05$ & $<0.05$ & YES & QUASI-FLEXIBLE \\
\hline & From 1973.9 to 1974.11 & $<0.05$ & $<0.05$ & $<0.05$ & YES & QUASI-FLEXIBLE \\
\hline & From 1974.12 to 1977.11 & $<0.05$ & $<0.05$ & $<0.05$ & YES & FIXED \\
\hline & From 1977.12 to 1998.9 & $<0.05$ & $<0.05$ & $<0.05$ & YES & QUASI-FLEXIBLE \\
\hline & From 1998.10 to 2006.12 & $>0.05$ & $<0.05$ & $<0.05$ & YES & FREELY FLOATING \\
\hline \multirow{7}{*}{$\begin{array}{c}\text { NETHERLANDS } \\
1963.3-1998.12\end{array}$} & From 1963.3 to 1981.7 & $>0.05$ & $>0.05$ & $>0.05$ & NO & FIXED \\
\hline & From 1981.8 to 1982.4 & $>0.05$ & {$[0.05,0.10]$} & {$[0.05,0.10]$} & YES* & FREELY FLOATING \\
\hline & From 1982.5 to 1983.12 & $>0.05$ & $>0.05$ & {$[0.05,0.10]$} & NO & FREELY FLOATING \\
\hline & From 1984.1 to 1986.3 & $>0.05$ & $>0.05$ & $>0.05$ & NO & FREELY FLOATING \\
\hline & From 1986.4 to 1991.6 & $>0.05$ & $>0.05$ & {$[0.05,0.10]$} & NO & FREELY FLOATING \\
\hline & From 1991.7 to 1997.3 & $>0.05$ & {$[0.05,0.10]$} & $<0.05$ & YES* & FREELY FLOATING \\
\hline & From 1997.4 to 1998.12 & $>0.05$ & {$[0.05,0.10]$} & {$[0.05,0.10]$} & YES* & FREELY FLOATING \\
\hline \multirow{7}{*}{$\begin{array}{l}\text { NEW ZEALAND } \\
\text { 1963.I-2003.IV }\end{array}$} & From 1963.I to $1967 . \mathrm{III}$ & $>0.05$ & $>0.05$ & $>0.05$ & NO & FIXED \\
\hline & From 1967.IV to 1971.II & $>0.05$ & $<0.05$ & $<0.05$ & YES & FIXED \\
\hline & From 1971.III to 1975.II & $>0.05$ & $>0.05$ & {$[0.05,0.10]$} & NO & FIXED \\
\hline & From 1975.III to 1977.IV & $>0.05$ & {$[0.05,0.10]$} & $<0.05$ & YES* & QUASI-FLEXIBLE \\
\hline & From 1978.I to 1981.I & $>0.05$ & $<0.05$ & $<0.05$ & YES & QUASI-FLEXIBLE \\
\hline & From 1981.II to 1982.III & {$[0.05,0.10]$} & $<0.05$ & $<0.05$ & YES & QUASI-FLEXIBLE \\
\hline & From 1982.IV to $1998 . I V$ & $<0.05$ & $<0.05$ & $<0.05$ & YES & FREELY FLOATING \\
\hline \multirow{7}{*}{$\begin{array}{c}\text { NORWAY } \\
1963.3-2006.12\end{array}$} & From 1963.3 to 1963.4 & $>0.05$ & $<0.05$ & $>0.05$ & NO & FIXED \\
\hline & From 1963.5 to 1963.7 & $>0.05$ & $>0.05$ & $>0.05$ & NO & FIXED \\
\hline & From 1963.8 to 1963.10 & $>0.05$ & $<0.05$ & $>0.05$ & NO & FIXED \\
\hline & From 1963.11 to 1974.11 & $>0.05$ & $>0.05$ & $>0.05$ & $\mathrm{NO}$ & FIXED \\
\hline & From 1974.12 to 1976.2 & $>0.05$ & {$[0.05,0.10]$} & $<0.05$ & YES* & FREELY FLOATING \\
\hline & From 1976.3 to 1977.7 & $>0.05$ & $<0.05$ & $<0.05$ & YES & FREELY FLOATING \\
\hline & From 1977.8 to 2006.12 & $<0.05$ & $<0.05$ & $<0.05$ & YES & FREELY FLOATING \\
\hline \multirow{6}{*}{$\begin{array}{l}\text { PORTUGAL } \\
\text { 1963.I-1998.IV }\end{array}$} & From 1963.I to 1978.I & $>0.05$ & $>0.05$ & $>0.05$ & NO & FIXED \\
\hline & From 1978.II to 1980.IV & $>0.05$ & $>0.05$ & {$[0.05,0.10]$} & NO & FREELY FLOATING \\
\hline & From 1981.I to 1982.II & $>0.05$ & {$[0.05,0.10]$} & $<0.05$ & YES* & FREELY FLOATING \\
\hline & From 1983.III to 1993.III & $>0.05$ & $<0.05$ & $<0.05$ & YES & FREELY FLOATING \\
\hline & From 1983.IV to $1998 . \mathrm{II}$ & $>0.05$ & {$[0.05,0.10]$} & $<0.05$ & YES* & FREELY FLOATING \\
\hline & From 1998.III to 1998.IV & $<0.05$ & $<0.05$ & $<0.05$ & YES & FREELY FLOATING \\
\hline \multirow{4}{*}{$\begin{array}{c}\text { SPAIN } \\
1963.3-1998.12\end{array}$} & From 1963.3 to 1977.6 & $>0.05$ & $>0.05$ & $>0.05$ & NO & FIXED \\
\hline & From 1977.7 to 1986.8 & $>0.05$ & {$[0.05,0.10]$} & $<0.05$ & YES* & FREELY FLOATING \\
\hline & From 1986.9 to 1987.10 & $>0.05$ & $>0.05$ & $<0.05$ & $\mathrm{NO}$ & FREELY FLOATING \\
\hline & From 1987.11 to 1998.12 & $>0.05$ & $>0.05$ & $>0.05$ & $\mathrm{NO}$ & FREELY FLOATING \\
\hline \multirow{3}{*}{$\begin{array}{c}\text { SWEDEN } \\
\text { 1963.3-2006.12 }\end{array}$} & From 1963.3 to 1981.9 & $>0.05$ & $>0.05$ & $>0.05$ & $\mathrm{NO}$ & FIXED \\
\hline & From 1981.10 to 1999.1 & $>0.05$ & {$[0.05,0.10]$} & {$[0.05,0.10]$} & YES* & FREELY FLOATING \\
\hline & From 1999.2 to 2006.12 & $<0.05$ & {$[0.05,0.10]$} & $<0.05$ & YES & FREELY FLOATING \\
\hline & From 1963.3 to 1973.1 & $>0.05$ & $>0.05$ & $>0.05$ & NO & FIXED \\
\hline \multirow[t]{2}{*}{$1963.3-2006.12$} & From 1973.2 to 1973.5 & $>0.05$ & $<0.05$ & $<0.05$ & YES & FIXED \\
\hline & From 1973.6 to 2006.12 & $<0.05$ & $<0.05$ & $<0.05$ & YES & FREELY FLOATING \\
\hline UNITED & From 1963.3 to 1972.5 & $>0.05$ & $>0.05$ & $>0.05$ & NO & FIXED \\
\hline KINGDOM & From 1972.6 to 1973.5 & $>0.05$ & $<0.05$ & $<0.05$ & YES & FREELY FLOATING \\
\hline $1963.3-2006.12$ & From 1973.6 to 2006.12 & $<0.05$ & $<0.05$ & $<0.05$ & YES & FREELY FLOATING \\
\hline
\end{tabular}

Notes: a. REER: real effective exchange rate; $\mathbf{b}$. Pvsup, Pvexp and Pvave are the p-values of the supreme test developed by Andrews (1993) and the exponential and average tests developed by Andrews and Ploberger (1994); c. YES: evidence of instability in the variance of the real exchange rate at $5 \%$ significant level, YES*. evidence of instability in the variance of the real exchange rate at $10 \%$ significant level, NO: no evidence of instability in the variance of the real exchange rate at 5\% significant level. d. Reinhart and Rogoff (2004)'s coarse grid classification. 
Table 4. Hansen's (1997) P-values of the Supreme, Exponential and Average Tests

\begin{tabular}{|c|c|c|c|c|c|c|}
\hline $\begin{array}{c}\text { NON-OECD } \\
\text { REER }^{\text {a }} \\
\end{array}$ & Periods & Pvsup $^{b}$ & Pvexp & Pvave & Instability $^{c}$ & R\&R Regimes ${ }^{\mathrm{d}}$ \\
\hline $\begin{array}{c}\text { BURKINA FASO } \\
1963.3-2006.10\end{array}$ & $\begin{array}{l}\text { From } 1963.3 \text { to } 1963.4 \\
\text { From } 1963.5 \text { to } 1972.9 \\
\text { From } 1972.10 \text { to } 1973.2 \\
\text { From } 1973.3 \text { to } 1975.6 \\
\text { From } 1975.7 \text { to } 2006.10\end{array}$ & $\begin{array}{l}>0.05 \\
>0.05 \\
>0.05 \\
>0.05 \\
<0.05\end{array}$ & $\begin{aligned}<0.05 \\
>0.05 \\
>0.05 \\
{[0.05,0.10] } \\
<0.05\end{aligned}$ & $\begin{array}{l}<0.05 \\
>0.05] \\
<0.05 \\
<0.05 \\
<0.05\end{array}$ & $\begin{array}{l}\text { YES } \\
\text { NO } \\
\text { NO } \\
\text { YES* } \\
\text { YES }\end{array}$ & $\begin{array}{c}\text { FIXED } \\
\text { FIXED } \\
\text { FIXED } \\
\text { QUASI-FLEXIBLE } \\
\text { FREELY FLOATING }\end{array}$ \\
\hline $\begin{array}{c}\text { COLOMBIA } \\
1963.3-2006.12\end{array}$ & $\begin{array}{l}\text { From } 1963.3 \text { to } 1963.8 \\
\text { From } 1963.9 \text { to } 2006.12\end{array}$ & $\begin{array}{l}<0.05 \\
>0.05\end{array}$ & $\begin{array}{l}<0.05 \\
>0.05\end{array}$ & $\begin{array}{l}<0.05 \\
>0.05\end{array}$ & $\begin{array}{l}\text { YES } \\
\text { NO }\end{array}$ & $\begin{array}{l}\text { FREELY FALLING } \\
\text { QUASI-FIXED }\end{array}$ \\
\hline $\begin{array}{c}\text { HAITI } \\
\text { 1963.3-2006.6 }\end{array}$ & $\begin{array}{l}\text { From } 1963.3 \text { to } 1984.3 \\
\text { From } 1984.4 \text { to } 1984.8 \\
\text { From } 1984.9 \text { to } 1991.8 \\
\text { From } 1991.9 \text { to } 2006.6\end{array}$ & $\begin{array}{l}>0.05 \\
>0.05 \\
<0.05 \\
>0.05\end{array}$ & $\begin{array}{l}>0.05 \\
<0.05 \\
<0.05 \\
>0.05\end{array}$ & $\begin{array}{l}>0.05 \\
<0.05] \\
<0.05 \\
>0.05\end{array}$ & $\begin{array}{l}\text { NO } \\
\text { YES } \\
\text { YES } \\
\text { NO }\end{array}$ & $\begin{array}{c}\text { FIXED } \\
\text { FIXED } \\
\text { FREELY FALLING } \\
\text { QUASI-FLEXIBLE }\end{array}$ \\
\hline $\begin{array}{l}\text { HONDURAS } \\
1963.3-2006.12\end{array}$ & $\begin{array}{l}\text { From } 1963.3 \text { to } 1963.6 \\
\text { From } 1963.7 \text { to } 1965.8 \\
\text { From } 1965.9 \text { to } 1967.2 \\
\text { From } 1967.3 \text { to } 1984.10 \\
\text { From } 1984.11 \text { to } 1990.2 \\
\text { From } 1990.3 \text { to } 2006.7\end{array}$ & $\begin{array}{l}>0.05 \\
>0.05 \\
<0.05 \\
>0.05 \\
<0.05 \\
>0.05\end{array}$ & $\begin{array}{l}>0.05 \\
<0.05 \\
<0.05 \\
>0.05 \\
<0.05 \\
>0.05\end{array}$ & $\begin{array}{l}>0.05 \\
<0.05 \\
>0.05 \\
>0.05 \\
<0.05 \\
>0.05\end{array}$ & $\begin{array}{l}\text { NO } \\
\text { YES } \\
\text { YES } \\
\text { NO } \\
\text { YES } \\
\text { NO }\end{array}$ & $\begin{array}{c}\text { FIXED } \\
\text { FIXED } \\
\text { FIXED } \\
\text { QUASI-FIXED } \\
\text { FREELY FALLING } \\
\text { FREELY FLOATING }\end{array}$ \\
\hline $\begin{array}{c}\text { ISRAEL } \\
1963.1-2006.12\end{array}$ & $\begin{array}{l}\text { From } 1963.3 \text { to } 1971.2 \\
\text { From } 1971.3 \text { to } 2006.12\end{array}$ & $\begin{array}{l}<0.05 \\
>0.05\end{array}$ & $\begin{array}{l}<0.05 \\
>0.05\end{array}$ & $\begin{array}{l}<0.05 \\
>0.05\end{array}$ & $\begin{array}{l}\text { YES } \\
\text { NO }\end{array}$ & $\begin{array}{c}\text { FIXED } \\
\text { QUASI-FIXED }\end{array}$ \\
\hline $\begin{array}{l}\text { IVORY COAST } \\
1963.1-2006.8\end{array}$ & $\begin{array}{l}\text { From } 1963.3 \text { to } 1982.6 \\
\text { From } 1982.7 \text { to } 1982.8 \\
\text { From } 1982.9 \text { to } 2006.12\end{array}$ & $\begin{array}{l}>0.05 \\
>0.05 \\
>0.05\end{array}$ & $\begin{array}{l}>0.05 \\
<0.05 \\
<0.05\end{array}$ & $\begin{array}{l}>0.05 \\
<0.05 \\
<0.05\end{array}$ & $\begin{array}{l}\text { NO } \\
\text { YES } \\
\text { YES }\end{array}$ & $\begin{array}{l}\text { N/A } \\
\text { N/A } \\
\text { N/A }\end{array}$ \\
\hline $\begin{array}{c}\text { JAMAICA } \\
1963.1-2006.12\end{array}$ & $\begin{array}{l}\text { From } 1963.3 \text { to } 1978.4 \\
\text { From } 1978.5 \text { to } 1981.3 \\
\text { From } 1981.4 \text { to } 1983.10 \\
\text { From } 1983.11 \text { to } 1984.7 \\
\text { From } 1984.8 \text { to } 2006.12\end{array}$ & $\begin{array}{l}>0.05 \\
>0.05 \\
>0.05 \\
>0.05 \\
<0.05\end{array}$ & $\begin{array}{l}>0.05 \\
<0.05 \\
>0.05 \\
<0.05 \\
<0.05\end{array}$ & $\begin{array}{l}>0.05 \\
<0.05] \\
<0.05 \\
<0.05 \\
<0.05\end{array}$ & $\begin{array}{l}\text { NO } \\
\text { YES } \\
\text { NO } \\
\text { YES } \\
\text { YES }\end{array}$ & $\begin{array}{c}\text { FIXED } \\
\text { FREELY FALLING } \\
\text { FIXED } \\
\text { QUASI-FLEXIBLE } \\
\text { FREELY FLOATING }\end{array}$ \\
\hline $\begin{array}{c}\text { MOROCCO } \\
1963.1-2006.12\end{array}$ & $\begin{array}{l}\text { From } 1963.3 \text { to } 1974.1 \\
\text { From } 1974.2 \text { to } 1978.9 \\
\text { From } 1978.10 \text { to } 1981.2 \\
\text { From } 1981.3 \text { to } 2006.12\end{array}$ & $\begin{array}{l}>0.05 \\
>0.05 \\
>0.05 \\
<0.05\end{array}$ & $\begin{array}{l}>0.05 \\
>0.05 \\
<0.05 \\
<0.05\end{array}$ & $\begin{array}{l}>0.05 \\
<0.05] \\
<0.05 \\
<0.05\end{array}$ & $\begin{array}{l}\text { NO } \\
\text { NO } \\
\text { YES } \\
\text { YES }\end{array}$ & $\begin{array}{c}\text { FIXED } \\
\text { FIXED } \\
\text { QUASI-FLEXIBLE } \\
\text { FREELY FLOATING }\end{array}$ \\
\hline $\begin{array}{l}\text { PHILLIPINES } \\
\text { 1963.1-2006.12 }\end{array}$ & $\begin{array}{l}\text { From } 1963.3 \text { to } 1968.10 \\
\text { From } 1968.11 \text { to } 1969.3 \\
\text { From } 1969.4 \text { to } 1969.6 \\
\text { From } 1969.7 \text { to } 1970.1 \\
\text { From } 1970.2 \text { to } 1979.11 \\
\text { From } 1979.12 \text { to } 1980.9 \\
\text { From } 1980.10 \text { to } 1983.9 \\
\text { From } 1983.10 \text { to } 1988.8 \\
\text { From } 1989.9 \text { to } 1990.3 \\
\text { From } 1990.4 \text { to } 1990.10 \\
\text { From } 1990.11 \text { to } 2006.12\end{array}$ & $\begin{array}{l}>0.05 \\
>0.05 \\
<0.05 \\
>0.05 \\
>0.05 \\
>0.05 \\
<0.05 \\
>0.05 \\
<0.05 \\
<0.05 \\
>0.05\end{array}$ & $\begin{array}{l}>0.05 \\
>0.05 \\
<0.05 \\
<0.05 \\
>0.05 \\
<0.05 \\
<0.05 \\
>0.05 \\
<0.05 \\
<0.05 \\
>0.05\end{array}$ & $\begin{array}{l}>0.05 \\
<0.05 \\
<0.05 \\
<0.05 \\
>0.05 \\
<0.05 \\
<0.05 \\
>0.05 \\
<0.05 \\
>0.05 \\
>0.05\end{array}$ & $\begin{array}{l}\text { NO } \\
\text { NO } \\
\text { YES } \\
\text { YES } \\
\text { YES } \\
\text { YES } \\
\text { YES } \\
\text { NO } \\
\text { NO } \\
\text { YES } \\
\text { NO }\end{array}$ & $\begin{array}{c}\text { FIXED } \\
\text { FIXED } \\
\text { FIXED } \\
\text { QUASI-FIXED } \\
\text { QUASI-FLEXIBLE } \\
\text { FREELY FALLING } \\
\text { QUASI-FLEXIBLE } \\
\text { QUASI-FIXED } \\
\text { QUASI-FIXED } \\
\text { QUASI-FLEXIBLE } \\
\text { QUASI-FLEXIBLE }\end{array}$ \\
\hline
\end{tabular}

Notes: a. REER: real effective exchange rate; b. Pvsup, Pvexp and Pvave are the p-values of the supreme test developed by Andrews (1993) and the exponential and average tests developed by Andrews and Ploberger (1994); c. YES: evidence of instability in the variance of the real exchange rate at 5\% significant level, YES*: evidence of instability in the variance of the real exchange rate at 10\% significant level, NO: no evidence of instability in the variance of the real exchange rate at 5\% significant level. d. Reinhart and Rogoff (2004)'s coarse grid classification. N/A= no available 
Table 4 (cont.). Hansen's (1997) P-values of the Supreme, Exponential and Average Tests

\begin{tabular}{|c|c|c|c|c|c|c|}
\hline $\begin{array}{c}\text { NON-OECD } \\
\text { REER }^{\mathrm{a}}\end{array}$ & Periods & Pvsup $^{b}$ & Pvexp & Pvave & Instability $^{c}$ & R\&R Regimes ${ }^{d}$ \\
\hline SOUTH AFRICA & From 1963.3 to 1972.8 & $>0.05$ & $>0.05$ & $>0.05$ & NO & FIXED \\
\hline \multirow{3}{*}{$1963.3-2006.12$} & From 1972.9 to 1973.1 & $>0.05$ & $>0.05$ & $<0.05]$ & NO & FIXED \\
\hline & From 1973.2 to 1973.3 & $<0.05$ & $<0.05$ & $<0.05$ & YES & QUASI-FLEXIBLE \\
\hline & From 1973.4 to 2006.12 & $<0.05$ & $<0.05$ & $<0.05$ & YES & FREELY FLOATING \\
\hline SRI LANKA & From 1963.3 to 1972.6 & $>0.05$ & $>0.05$ & $>0.05$ & NO & QUASI-FIXED \\
\hline \multirow{5}{*}{ 1963.1-2006.12 } & From 1972.7 to 1972.12 & $>0.05$ & $>0.05$ & $<0.05$ & NO & QUASI-FIXED \\
\hline & From 1973.1 to 1974.2 & $>0.05$ & $<0.05$ & $<0.05$ & YES & QUASI-FIXED \\
\hline & From 1974.3 to 1977.12 & $<0.05$ & $<0.05$ & $<0.05$ & YES & QUASI-FLEXIBLE \\
\hline & From 1978.1 to 1981.12 & $>0.05$ & $<0.05$ & $<0.05$ & YES & QUASI-FLEXIBLE \\
\hline & From 1982.1 to 2006.12 & $<0.05$ & $<0.05$ & $<0.05$ & YES & QUASI-FLEXIBLE \\
\hline TRINIDAD AND & From 1963.3 to 1973.9 & $>0.05$ & $>0.05$ & $>0.05$ & NO & N/A \\
\hline TOBAGO & From 1973.10 to 1974.1 & $>0.05$ & $>0.05$ & $<0.05$ & NO & N/A \\
\hline \multirow{8}{*}{$1963.3-2006.10$} & From 1974.2 to 1988.8 & $>0.05$ & $<0.05$ & $<0.05$ & YES & N/A \\
\hline & From 1988.9 to 1990.8 & $<0.05$ & $<0.05$ & $<0.05$ & YES & N/A \\
\hline & From 1990.9 to 1991.4 & $>0.05$ & $<0.05$ & $>0.05$ & NO & N/A \\
\hline & From 1991.5 to 1993.4 & $>0.05$ & $>0.05$ & $>0.05$ & NO & N/A \\
\hline & From 1993.5 to 1994.6 & $<0.05$ & $<0.05$ & $<0.05$ & YES & N/A \\
\hline & From 1994.7 to 1996.10 & $<0.05$ & $<0.05$ & $>0.05$ & YES & N/A \\
\hline & From 1996.11 to 1999.6 & $>0.05$ & $>0.05$ & $>0.05$ & NO & N/A \\
\hline & From 1999.7 to 2006.10 & $<0.05$ & $<0.05$ & $<0.05$ & YES & N/A \\
\hline & From 1963.3 to 1970.5 & $>0.05$ & $>0.05$ & $>0.05$ & NO & FIXED \\
\hline \multirow[t]{5}{*}{ 1963.1-2006.11 } & From 1970.6 to 1974.6 & $>0.05$ & {$[0.05,0.10]$} & $<0.05$ & YES* & FIXED \\
\hline & From 1974.7 to 1978.6 & $>0.05$ & $>0.05$ & $>0.05$ & NO & FIXED \\
\hline & From 1978.7 to 1978.12 & $>0.05$ & $>0.05$ & $<0.05$ & NO & FIXED \\
\hline & From 1979.1 to 1985.12 & $>0.05$ & $>0.05$ & $>0.05$ & NO & QUASI-FLEXIBLE \\
\hline & From 1986.1 to 2006.11 & $<0.05$ & $<0.05$ & $<0.05$ & YES & QUASI-FLEXIBLE \\
\hline
\end{tabular}

Notes

a. REER: real effective exchange rate.
b. Pvsup, Pvexp and Pvave are the p-values of the supreme test developed by Andrews (1993)

and the exponential and average tests developed by Andrews and Ploberger (1994).

c. YES: evidence of instability in the variance of the real exchange rate at 5\% significant level, YES*:

evidence of instability in the variance of the real exchange rate at 10\% significant level, NO: no evidence

of instability in the variance of the real exchange rate at $5 \%$ significant level.

d. Reinhart and Rogoff (2004)'s coarse grid classification.

$\mathrm{N} / \mathrm{A}=$ no available 
Table 5 (a). Volatility by Sub-periods

\begin{tabular}{|c|c|c|c|}
\hline 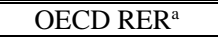 & Periods & Instability $^{\mathrm{b}}$ & Volatility \\
\hline $\begin{array}{l}\text { AUSTRALIA } \\
\text { 1963.I- 2003.IV }\end{array}$ & $\begin{array}{l}\text { From 1963.I to 1963.IV } \\
\text { From 1964.I to 1973.III } \\
\text { From 1973.IV 2003.IV }\end{array}$ & $\begin{array}{l}\text { yes } \\
\text { no } \\
\text { yes }\end{array}$ & $\begin{array}{l}\text { high: yes } \\
\text { low: yes } \\
\text { high: yes }\end{array}$ \\
\hline $\begin{array}{c}\text { AUSTRIA } \\
1963.3-1998.12\end{array}$ & $\begin{array}{l}\text { From } 1963.1 \text { to } 1968.6 \\
\text { From } 1968.7 \text { to } 1971.4 \\
\text { From } 1971.5 \text { to } 1974.11 \\
\text { From } 1974.12 \text { to } 1998.12\end{array}$ & $\begin{array}{c}\text { no } \\
\text { yes } \\
\text { no } \\
\text { yes }\end{array}$ & $\begin{array}{l}\text { low: no } \\
\text { high: no } \\
\text { low: yes } \\
\text { high: yes }\end{array}$ \\
\hline $\begin{array}{c}\text { BELGIUM } \\
\text { 1963.3-1998.12 }\end{array}$ & $\begin{array}{l}\text { From } 1963.1 \text { to } 1974.1 \\
\text { From } 1974.2 \text { to } 1998.12\end{array}$ & $\begin{array}{l}\text { no } \\
\text { yes }\end{array}$ & $\begin{array}{l}\text { low: yes } \\
\text { high: yes }\end{array}$ \\
\hline $\begin{array}{c}\text { CANADA } \\
1963.3-2006.12\end{array}$ & $\begin{array}{l}\text { From } 1963.3 \text { to } 1979.5 \\
\text { From } 1979.6 \text { to } 2006.12\end{array}$ & $\begin{array}{l}\text { no } \\
\text { yes }\end{array}$ & $\begin{array}{l}\text { low: yes } \\
\text { high: yes }\end{array}$ \\
\hline $\begin{array}{l}\text { DENMARK } \\
\text { 1963.I-2003.IV }\end{array}$ & $\begin{array}{l}\text { From 1963.I to } 1975 . \mathrm{II} \\
\text { From 1975.III to 2003.IV }\end{array}$ & $\begin{array}{l}\text { no } \\
\text { yes }\end{array}$ & $\begin{array}{l}\text { low: yes } \\
\text { high: yes }\end{array}$ \\
\hline $\begin{array}{l}\text { FINLAND } \\
\text { 1963.I-1998.IV }\end{array}$ & $\begin{array}{l}\text { From 1963.I to } 1963 . I V \\
\text { From 1964.I to 1964.III } \\
\text { From 1964.IV to 1967.III } \\
\text { From 1967.IV to 1969.II } \\
\text { From 1970.IV to 1974.III } \\
\text { From 1974.IV to 1998.IV }\end{array}$ & $\begin{array}{c}\text { no } \\
\text { yes } \\
\text { no } \\
\text { yes } \\
\text { no } \\
\text { yes }\end{array}$ & $\begin{array}{l}\text { low: yes } \\
\text { high: yes } \\
\text { low: yes } \\
\text { high: yes } \\
\text { low: yes } \\
\text { high: yes }\end{array}$ \\
\hline $\begin{array}{c}\text { FRANCE } \\
1963.3-1998.12\end{array}$ & $\begin{array}{l}\text { From } 1963.3 \text { to } 1973.12 \\
\text { From } 1974.1 \text { to } 1998.12\end{array}$ & $\begin{array}{l}\text { no } \\
\text { yes }\end{array}$ & $\begin{array}{l}\text { low: yes } \\
\text { high: yes }\end{array}$ \\
\hline $\begin{array}{c}\text { GERMANY } \\
1963.3-1998.12\end{array}$ & $\begin{array}{l}\text { From } 1963.3 \text { to } 1973.2 \\
\text { From } 1973.3 \text { to } 1998.12\end{array}$ & $\begin{array}{l}\text { no } \\
\text { yes }\end{array}$ & $\begin{array}{l}\text { low: yes } \\
\text { high: yes }\end{array}$ \\
\hline $\begin{array}{c}\text { GREECE } \\
1963.3-1998.12\end{array}$ & $\begin{array}{l}\text { From } 1963.3 \text { to } 1974.3 \\
\text { From } 1974.4 \text { to } 1998.12\end{array}$ & $\begin{array}{l}\text { no } \\
\text { yes }\end{array}$ & $\begin{array}{l}\text { low: yes } \\
\text { high: yes }\end{array}$ \\
\hline $\begin{array}{l}\text { IRELAND } \\
\text { 1963.I-1998.IV }\end{array}$ & $\begin{array}{l}\text { From 1963.I to1976.I } \\
\text { From 1976.II to 1998.IV }\end{array}$ & $\begin{array}{l}\text { no } \\
\text { yes }\end{array}$ & $\begin{array}{l}\text { low: yes } \\
\text { high: yes }\end{array}$ \\
\hline $\begin{array}{c}\text { ITALY } \\
1963.3-1998.12\end{array}$ & $\begin{array}{l}\text { From } 1963.3 \text { to } 1975.6 \\
\text { From } 1975.7 \text { to } 1998.12\end{array}$ & $\begin{array}{l}\text { no } \\
\text { yes }\end{array}$ & $\begin{array}{l}\text { low: yes } \\
\text { high: yes }\end{array}$ \\
\hline $\begin{array}{c}\text { JAPAN } \\
1963.3-2006.12\end{array}$ & $\begin{array}{l}\text { From } 1963.3 \text { to } 1974.9 \\
\text { From } 1974.10 \text { to } 2006.12\end{array}$ & $\begin{array}{l}\text { no } \\
\text { yes }\end{array}$ & $\begin{array}{l}\text { low: yes } \\
\text { high: yes }\end{array}$ \\
\hline $\begin{array}{c}\text { KOREA } \\
1963.3-2006.12\end{array}$ & $\begin{array}{l}\text { From } 1963.3 \text { to } 1964.4 \\
\text { From } 1964.5 \text { to } 1964.12 \\
\text { From } 1965.1 \text { to } 1966.12 \\
\text { From } 1967.1 \text { to } 2006.12\end{array}$ & $\begin{array}{c}\text { no } \\
\text { yes } \\
\text { no } \\
\text { yes }\end{array}$ & $\begin{array}{l}\text { low: yes } \\
\text { high: yes } \\
\text { low: yes } \\
\text { high: yes }\end{array}$ \\
\hline $\begin{array}{l}\text { LUXEMBURG } \\
\text { 1963.I-1998.IV }\end{array}$ & $\begin{array}{l}\text { From 1963.I to 1971.IV } \\
\text { From 1972.I to 1998.IV }\end{array}$ & $\begin{array}{l}\text { no } \\
\text { yes }\end{array}$ & $\begin{array}{l}\text { low: yes } \\
\text { high: yes }\end{array}$ \\
\hline $\begin{array}{l}\text { NETHERLANDS } \\
1963.3-1998.12\end{array}$ & $\begin{array}{l}\text { From } 1963.3 \text { to } 1967.10 \\
\text { From } 1967.11 \text { to } 1968.6 \\
\text { From } 1968.7 \text { to } 1975.1 \\
\text { From } 1975.2 \text { to } 1998.12\end{array}$ & $\begin{array}{c}\text { no } \\
\text { yes } \\
\text { no } \\
\text { yes }\end{array}$ & $\begin{array}{l}\text { low: no } \\
\text { high: no } \\
\text { low: yes } \\
\text { high: yes }\end{array}$ \\
\hline $\begin{array}{l}\text { NEW ZEALAND } \\
\text { 1963.I-2003.IV }\end{array}$ & $\begin{array}{l}\text { From 1963.I to } 1967 . \mathrm{II} \\
\text { From 1967.III to } 1972 . \mathrm{IV} \\
\text { From 1973.I to } 1975 . \mathrm{II} \\
\text { From 1975.III to 2003.IV }\end{array}$ & $\begin{array}{c}\text { no } \\
\text { yes } \\
\text { no } \\
\text { yes }\end{array}$ & $\begin{array}{l}\text { low: yes } \\
\text { high: yes } \\
\text { low: no } \\
\text { high: no }\end{array}$ \\
\hline
\end{tabular}

Notes: a. RER: real exchange rate; b. yes: evidence of instability in the variance of the real exchange rate at $5 \%$ significant level, no: no evidence of instability in the variance of the real exchange rate at $5 \%$ significant level.; c. Shadow cells indicate that periods with evidence of instability present an higher volatility than more tranquil periods. 
Table 5 (a) (cont.). Volatility by Sub-periods

\begin{tabular}{|c|c|c|c|}
\hline OECD RER $^{\mathrm{a}}$ & Periods & Instability $^{\mathrm{b}}$ & Volatility \\
\hline NORWAY & From 1963.3 to 1973.5 & no & low: yes \\
\hline $1963.3-2006.12$ & From 1973.6 to 2006.12 & yes & high: yes \\
\hline PORTUGAL & From 1963.I to 1973.IV & no & low: yes \\
\hline 1963.I-1998.IV & From 1974.I to 1998.IV & yes & high: yes \\
\hline SPAIN & From 1963.3 to 1981.3 & no & low: yes \\
\hline 1963.3-1998.12 & From 1981.4 to 1998.12 & yes & high: yes \\
\hline SWEDEN & From 1963.3 to 1970.1 & no & low: yes \\
\hline $1963.3-2006.12$ & From 1970.2 to 2006.12 & yes & high: yes \\
\hline SWITZERLAND & From 1963.3 to 1972.4 & no & low: yes \\
\hline 1963.3-2006.12 & From 1972.5 to 2006.12 & yes & high: yes \\
\hline UNITED & From 1963.3 to 1973.8 & no & low: yes \\
\hline KINGDOM & From 1973.9 to 2006.12 & yes & high: yes \\
\hline 1963.3-2006.12 & & & \\
\hline
\end{tabular}

a. RER: real exchange rate.

b. yes: evidence of instability in the variance of the real exchange rate at 5\% significant level, no: no evidence of instability in the variance of the real exchange rate at $5 \%$ significant level.

c. Shadow cells indicate that periods with evidence of instability present an higher volatility than more tranquil periods. 
Table 5 (b). Volatility by Sub-periods

\begin{tabular}{|c|c|c|c|}
\hline $\begin{array}{c}\text { NON-OECD } \\
\text { RER }^{\mathrm{a}}\end{array}$ & Periods & Instability $^{\mathrm{b}}$ & Volatility \\
\hline $\begin{array}{c}\text { BURKINA FASO } \\
1963.3-2006.10\end{array}$ & $\begin{array}{l}\text { From } 1963.3 \text { to } 1973.8 \\
\text { From } 1973.9 \text { to } 2006.10\end{array}$ & $\begin{array}{c}\text { no } \\
\text { yes }\end{array}$ & $\begin{array}{l}\text { low: yes } \\
\text { high: yes }\end{array}$ \\
\hline $\begin{array}{c}\text { CYPRUS } \\
1963.3-2006.12\end{array}$ & $\begin{array}{l}\text { From } 1963.3 \text { to } 1981.7 \\
\text { From } 1981.8 \text { to } 2006.12\end{array}$ & $\begin{array}{c}\text { no } \\
\text { yes }\end{array}$ & $\begin{array}{l}\text { low: yes } \\
\text { high: yes }\end{array}$ \\
\hline $\begin{array}{l}\text { DOMINICAN } \\
\text { REPUBLIC } \\
\text { 1963.3-2006.5 }\end{array}$ & $\begin{array}{l}\text { From } 1963.3 \text { to } 1976.6 \\
\text { From } 1976.7 \text { to } 1975.11 \\
\text { From } 1976.12 \text { to } 1977.10 \\
\text { From } 1977.11 \text { to } 1978.2 \\
\text { From } 1978.3 \text { to } 1978.8 \\
\text { From } 1978.9 \text { to } 1979.11 \\
\text { From } 1979.12 \text { to } 1981.12 \\
\text { From } 1982.1 \text { to } 1984.12 \\
\text { From } 1985.1 \text { to } 1987.8 \\
\text { From } 1987.9 \text { to } 1993.1 \\
\text { From } 1993.2 \text { to } 1996.9 \\
\text { From } 1996.10 \text { to } 2003.9 \\
\text { From } 2003.10 \text { to } 2006.5\end{array}$ & $\begin{array}{l}\text { no } \\
\text { yes } \\
\text { no } \\
\text { yes } \\
\text { no } \\
\text { yes } \\
\text { no } \\
\text { yes } \\
\text { no } \\
\text { yes } \\
\text { no } \\
\text { yes } \\
\text { no }\end{array}$ & $\begin{array}{l}\text { low: no } \\
\text { high: no } \\
\text { low: yes } \\
\text { high: yes } \\
\text { low: yes } \\
\text { high: yes } \\
\text { low: no } \\
\text { high: no } \\
\text { low: no } \\
\text { high: no } \\
\text { low: yes } \\
\text { high: yes } \\
\text { low: yes }\end{array}$ \\
\hline $\begin{array}{c}\text { EL SALVADOR } \\
1963.3-2006.12\end{array}$ & $\begin{array}{l}\text { From } 1963.3 \text { to } 1990.4 \\
\text { From } 1990.5 \text { to } 2006.12\end{array}$ & $\begin{array}{c}\text { no } \\
\text { yes }\end{array}$ & $\begin{array}{l}\text { low: no } \\
\text { high: no }\end{array}$ \\
\hline $\begin{array}{c}\text { EGYPT } \\
\text { 1963.I-1998.IV }\end{array}$ & $\begin{array}{l}\text { From } 1963.3 \text { to } 1963.9 \\
\text { From } 1963.10 \text { to } 1963.12 \\
\text { From } 1964.1 \text { to } 1964.11 \\
\text { From } 1964.12 \text { to } 1982.3 \\
\text { From } 1982.4 \text { to } 1982.6 \\
\text { From } 1982.7 \text { to } 1985.5 \\
\text { From } 1985.6 \text { to } 2006.12\end{array}$ & $\begin{array}{l}\text { yes } \\
\text { no } \\
\text { yes } \\
\text { no } \\
\text { yes } \\
\text { no } \\
\text { yes }\end{array}$ & $\begin{array}{l}\text { high: no } \\
\text { low: no } \\
\text { high: no } \\
\text { low: yes } \\
\text { high: yes } \\
\text { low: yes } \\
\text { high: yes }\end{array}$ \\
\hline $\begin{array}{c}\text { HAITI } \\
\text { 1963.3-2006.6 }\end{array}$ & $\begin{array}{l}\text { From } 1963.3 \text { to } 1984.3 \\
\text { From } 1984.4 \text { to } 1991.8 \\
\text { From } 1991.9 \text { to } 2006.6\end{array}$ & $\begin{array}{l}\text { no } \\
\text { yes } \\
\text { No }\end{array}$ & $\begin{array}{l}\text { low: no } \\
\text { high: no } \\
\text { low: no }\end{array}$ \\
\hline $\begin{array}{l}\text { HONDURAS } \\
\text { 1963.3-2006.12 }\end{array}$ & $\begin{array}{l}\text { From } 1963.3 \text { to } 1965.8 \\
\text { From } 1965.9 \text { to } 1967.2 \\
\text { From } 1967.3 \text { to } 1988.3 \\
\text { From } 1988.4 \text { to } 1989.6 \\
\text { From } 1989.7 \text { to } 2006.12\end{array}$ & $\begin{array}{c}\text { no } \\
\text { yes } \\
\text { no } \\
\text { yes } \\
\text { nono }\end{array}$ & $\begin{array}{l}\text { low: yes } \\
\text { high: yes } \\
\text { low: yes } \\
\text { high: yes } \\
\text { low: yes }\end{array}$ \\
\hline $\begin{array}{l}\text { ISRAEL } \\
\text { 1963.3-2006.12 }\end{array}$ & $\begin{array}{l}\text { From } 1963.3 \text { to } 1971.3 \\
\text { From } 1971.4 \text { to } 2006.12\end{array}$ & $\begin{array}{l}\text { yes } \\
\text { Noyes }\end{array}$ & $\begin{array}{l}\text { low: yes } \\
\text { high: yes }\end{array}$ \\
\hline $\begin{array}{c}\text { IVORY COAST } \\
1963.3-2006.8\end{array}$ & $\begin{array}{l}\text { From } 1963.3 \text { to } 1982.6 \\
\text { From } 1982.7 \text { to } 1983.4 \\
\text { From } 1983.5 \text { to } 1984.2 \\
\text { From } 1984.3 \text { to } 1984.11 \\
\text { From } 1984.12 \text { to } 1985.7 \\
\text { From } 1985.8 \text { to } 1987.5 \\
\text { From 1987.6 to } 1994.1 \\
\text { From 1994.2 to } 1996.7 \\
\text { From } 1996.8 \text { to } 2006.8\end{array}$ & $\begin{array}{l}\text { no } \\
\text { yes } \\
\text { no } \\
\text { yes } \\
\text { no } \\
\text { yes } \\
\text { No }\end{array}$ & $\begin{array}{l}\text { low: no } \\
\text { high: no } \\
\text { low: yes } \\
\text { high: yes } \\
\text { low: yes } \\
\text { high: yes } \\
\text { low: yes } \\
\text { high: yes } \\
\text { low: yes }\end{array}$ \\
\hline $\begin{array}{l}\text { JAMAICA } \\
1963.3-2006.12\end{array}$ & $\begin{array}{l}\text { From } 1963.3 \text { to } 1978.4 \\
\text { From } 1978.5 \text { to } 1980.11 \\
\text { From } 1980.12 \text { to } 1983.12 \\
\text { From } 1984.1 \text { to } 2006.12\end{array}$ & $\begin{array}{l}\text { no } \\
\text { yes } \\
\text { no } \\
\text { yes }\end{array}$ & $\begin{array}{l}\text { low: no } \\
\text { high: no } \\
\text { low: yes } \\
\text { high: yes }\end{array}$ \\
\hline $\begin{array}{c}\text { MALTA } \\
1963.3-2006.10 \\
\end{array}$ & $\begin{array}{l}\text { From } 1963.3 \text { to } 1973.12 \\
\text { From } 1974.1 \text { to } 12006.10\end{array}$ & $\begin{array}{c}\text { no } \\
\text { yes }\end{array}$ & $\begin{array}{l}\text { low: yes } \\
\text { high: yes }\end{array}$ \\
\hline
\end{tabular}

Notes: a. RER: real exchange rate; b. yes: evidence of instability in the variance of the real exchange rate at $5 \%$ significant level, no: no evidence of instability in the variance of the real exchange rate at $5 \%$ significant level; c. Shadow cells indicate that periods with evidence of instability present an higher volatility than more tranquil periods. 
Table 5 (b) (cont.). Volatility by Sub-periods

\begin{tabular}{|c|c|c|c|}
\hline $\begin{array}{c}\text { NON-OECD } \\
\text { RER }^{\mathrm{a}} \\
\end{array}$ & Periods & Instability $^{\mathrm{b}}$ & Volatility \\
\hline MOROCCO & From 1963.3 to 1978.12 & no & low: yes \\
\hline $1963.3-2006.12$ & From 1979.1 to 2006.12 & yes & high: yes \\
\hline PHILIPPINES & From 1963.3 to 1969.4 & no & low: no \\
\hline \multirow[t]{6}{*}{ 1963.3-2006.12 } & From 1969.5 to 1970.1 & yes & high: no \\
\hline & From 1970.2 to 1979.8 & no & low: yes \\
\hline & From 1979.9 to 1983.9 & yes & high: yes \\
\hline & From 1983.10 to 1990.3 & no & low: yes \\
\hline & From 1990.4 to 1990.8 & yes & high: yes \\
\hline & From 1990.9 to 2006.12 & no & low: yes \\
\hline SOUTH AFRICA & From 1963.3 to 1973.1 & no & low: yes \\
\hline 1963.3-2006.12 & From 1973.2 to 2006.12 & yes & high: yes \\
\hline SRI LANKA & From 1963.3 to 1973.7 & no & low: yes \\
\hline 1963.3-2006.12 & From 1973.8 to 2006.12 & yes & high: yes \\
\hline TRINIDAD AND & From 1963.3 to 1974.1 & no & low: yes \\
\hline TOBAGO & From 1974.2 to 1990.12 & yes & high: yes \\
\hline \multirow{4}{*}{$1963.3-2006.10$} & From 1991.1 to 1993.4 & no & low: no \\
\hline & From 1993.5 to 1995.7 & yes & high: no \\
\hline & From 1995.8 to 1999.6 & no & low: yes \\
\hline & From 1999.7 to 2006.10 & yes & high: yes \\
\hline \multicolumn{4}{|l|}{ VENEZUELA } \\
\hline \multirow{6}{*}{$1963.3-2006.11$} & From 1963.3 to 1969.2 & no & low: no \\
\hline & From 1969.3 to 1973.12 & yes & high: no \\
\hline & From 1974.1 to 1978.6 & no & low: yes \\
\hline & From 1978.7 to 1979.9 & yes & high: yes \\
\hline & From 1979.10 to 1985.9 & no & low: yes \\
\hline & From 1985.1 to 2006.12 & yes & high: yes \\
\hline
\end{tabular}

a. RER: real exchange rate.

b. yes: evidence of instability in the variance of the real exchange rate at 5\% significant level, no: no evidence of instability in the variance of the real exchange rate at 5\% significant level.

c. Shadow cells indicate that periods with evidence of instability present an higher volatility than more tranquil periods. 
Table 5 (c). Volatility by Sub-periods

\begin{tabular}{|c|c|c|c|}
\hline OECD REER ${ }^{\mathrm{a}}$ & Periods & Instability $^{\mathrm{b}}$ & Volatility \\
\hline AUSTRALIA & From 1963.I to 1973.II & no & low: yes $^{c}$ \\
\hline 1963.I- 2003.IV & From 1973.III-2003.IV & yes & high: yes \\
\hline BELGIUM & From 1963.3 to 1973.2 & no & low: yes \\
\hline $1963.3-1998.12$ & From 1973.3 to 1998.12 & yes & high: yes \\
\hline CANADA & From 1963.3 to 1978.9 & no & low: yes \\
\hline $1963.3-2006.12$ & From 1978.10 to 2006.12 & yes & high: yes \\
\hline DENMARK & From 1963.I to $1987 . \mathrm{III}$ & no & low: yes \\
\hline 1963.I-2003.IV & From 1987.IV to 2003.IV & yes & high: yes \\
\hline \multirow{4}{*}{$\begin{array}{l}\text { FINLAND } \\
\text { 1963.I-1998.IV }\end{array}$} & From 1963.I to $1967 . I V$ & no & low: no \\
\hline & From 1968.I to $1972 . I V$ & yes & high: no \\
\hline & From 1973.I to 1985.I & no & low: yes \\
\hline & From 1985.II to 1998.IV & yes & high: yes \\
\hline FRANCE & From 1963.3 to 1974.2 & no & low: yes \\
\hline 1963.3-1998.12 & From 1974.3 to 1998.12 & yes & high: yes \\
\hline GERMANY & From 1963.3 to 1974.6 & no & low: yes \\
\hline $1963.3-1998.12$ & From 1974.7 to 1998.12 & yes & high: yes \\
\hline \multirow{3}{*}{$\begin{array}{c}\text { GREECE } \\
1963.3-1998.12\end{array}$} & From 1963.3 to 1969.12 & yes & high: no \\
\hline & From 1970.1 to 1988.5 & no & low: no \\
\hline & From 1988.6 to 1998.12 & yes & high: no \\
\hline IRELAND & From 1963.I to1973.IV & no & low: yes \\
\hline 1963.I-1998.IV & From 1974.I to 1998.IV & yes & high: yes \\
\hline ITALY & From 1963.3 to 1974.9 & no & low: yes \\
\hline $1963.3-1998.12$ & From 1974.10 to 1998.12 & yes & high: yes \\
\hline JAPAN & From 1963.3 to 1975.1 & no & low: yes \\
\hline 1963.3-2006.12 & From 1975.2 to 2006.12 & yes & high: yes \\
\hline KOREA & From 1963.to 1966.12 & no & low: no \\
\hline $1963.3-2006.12$ & From 1967.1 to 2006.12 & yes & high: no \\
\hline NETHERLANDS & From 1963.3 to 1981.7 & no & low: yes \\
\hline \multirow[t]{3}{*}{$1963.3-1998.12$} & From 1981.8 to 1982.4 & yes & high: yes \\
\hline & From 1982.5 to 1991.6 & no & low: no \\
\hline & From 1991.7 to 1998.12 & yes & high: nos \\
\hline NEW ZEALAND & From 1963.I to 1967. III & no & low: yes \\
\hline \multirow{3}{*}{ 1963.I-2003.IV } & From 1967.IV to 1971.II & yes & high: yes \\
\hline & From 1971.III to 1975.II & no & low: yes \\
\hline & From 1975.III to 2003.IV & yes & high: yes \\
\hline
\end{tabular}

Notes

b. yes: evidence of instability in the variance of the real exchange rate at $5 \%$ significant level, no: no evidence of instability in the variance of the real exchange rate at $5 \%$ significant level. c. Shadow cells indicate that periods with evidence of instability present an higher volatility than more tranquil periods. 
Table 5 (c) (cont.). Volatility by Sub-periods

\begin{tabular}{|c|c|c|c|}
\hline OECD REER $^{\mathrm{a}}$ & Periods & Instability $^{\mathrm{b}}$ & Volatility \\
\hline NORWAY & From 1963.3 to 1974.11 & no & low: yes \\
\hline $1963.3-2006.12$ & From 1974.12 to 2006.12 & yes & high: yes \\
\hline PORTUGAL & From 1963.I to $1980 . I V$ & no & low: no \\
\hline 1963.I-1998.IV & From 1981.I to 1998.IV & yes & high: no \\
\hline \multirow{3}{*}{$\begin{array}{c}\text { SPAIN } \\
1963.3-1998.12\end{array}$} & From 1963.3 to 1977.6 & no & low: yes \\
\hline & From 1977.7 to 1986.8 & Yes & high: yes \\
\hline & From 1986.9 to 1998.12 & no & low: yes \\
\hline SWEDEN & From 1963.3 to 1981.9 & no & low: no \\
\hline $1963.3-2006.12$ & From 1981.10 to 2006.12 & yes & high: no \\
\hline SWITZERLAND & From 1963.3 to 1973.1 & no & low: yes \\
\hline $1963.3-2006.12$ & From 1973.25 to 2006.12 & yes & high: yes \\
\hline UNITED & From 1963.3 to 1972.5 & no & low: yes \\
\hline KINGDOM & From 1972.6 to 2006.12 & yes & high: yes \\
\hline 1963.3-2006.12 & & & \\
\hline
\end{tabular}

a. REER: real effective exchange rate.

b. yes: evidence of instability in the variance of the real exchange rate at 5\% significant level, no: no evidence of instability in the variance of the real exchange rate at $5 \%$ significant level.

c. Shadow cells indicate that periods with evidence of instability present an higher volatility than more tranquil periods. 
Table 5 (d). Volatility by Sub-periods

\begin{tabular}{|c|c|c|c|}
\hline $\begin{array}{c}\text { NON-OECD } \\
\text { REER }^{\mathrm{a}} \\
\end{array}$ & Periods & Instability $^{\mathrm{b}}$ & $\begin{array}{l}\text { Volatility } \\
\end{array}$ \\
\hline $\begin{array}{c}\text { BURKINA FASO } \\
1963.3-2006.10\end{array}$ & $\begin{array}{l}\text { From } 1963.3 \text { to } 1973.8 \\
\text { From } 1973.9 \text { to } 2006.10\end{array}$ & $\begin{array}{l}\text { no } \\
\text { yes }\end{array}$ & $\begin{array}{l}\text { low: yes } \\
\text { high: yes }\end{array}$ \\
\hline $\begin{array}{c}\text { COLOMBIA } \\
1963.3-2006.12\end{array}$ & $\begin{array}{l}\text { From 1963.3-1963.8 } \\
\text { From 1963.9-2006.12 }\end{array}$ & $\begin{array}{c}\text { yes } \\
\text { no }\end{array}$ & $\begin{array}{l}\text { high: yes } \\
\text { low: yes }\end{array}$ \\
\hline $\begin{array}{c}\text { HAITI } \\
1963.3-2006.6\end{array}$ & $\begin{array}{l}\text { From } 1963.3 \text { to } 1984.3 \\
\text { From } 1984.4 \text { to } 1991.8 \\
\text { From } 1991.9 \text { to } 2006.6\end{array}$ & $\begin{array}{l}\text { no } \\
\text { yes } \\
\text { No }\end{array}$ & $\begin{array}{l}\text { low: no } \\
\text { high: no } \\
\text { low: no }\end{array}$ \\
\hline $\begin{array}{l}\text { HONDURAS } \\
\text { 1963.3-2006.12 }\end{array}$ & $\begin{array}{l}\text { From } 1963.3 \text { to } 1963.6 \\
\text { From } 1963.7 \text { to } 1967.2 \\
\text { From } 1967.3 \text { to } 1984.10 \\
\text { From } 1984.11 \text { to } 1990.2 \\
\text { From } 1990.3 \text { to } 2006.12\end{array}$ & $\begin{array}{c}\text { no } \\
\text { yes } \\
\text { no } \\
\text { yes } \\
\text { no }\end{array}$ & $\begin{array}{l}\text { low: no } \\
\text { high: no } \\
\text { low: no } \\
\text { high: no } \\
\text { low: no }\end{array}$ \\
\hline $\begin{array}{c}\text { ISRAEL } \\
\text { 1963.3-2006.12 }\end{array}$ & $\begin{array}{l}\text { From } 1963.3 \text { to } 1971 . \\
\text { From } 1971.3 \text { to } 2006.12\end{array}$ & $\begin{array}{c}\text { yes } \\
\text { no }\end{array}$ & $\begin{array}{l}\text { low: yes } \\
\text { high: yes }\end{array}$ \\
\hline $\begin{array}{r}\text { IVORY COAST } \\
1963.3-2006.8\end{array}$ & $\begin{array}{l}\text { From } 1963.3 \text { to } 1982.6 \\
\text { From } 1982.7 \text { to } 2006.8\end{array}$ & $\begin{array}{l}\text { no } \\
\text { yes }\end{array}$ & $\begin{array}{l}\text { low: yes } \\
\text { high: yes }\end{array}$ \\
\hline $\begin{array}{c}\text { JAMAICA } \\
\text { 1963.3-2006.12 }\end{array}$ & $\begin{array}{l}\text { From } 1963.3 \text { to } 1978.4 \\
\text { From } 1978.5 \text { to } 1981.3 \\
\text { From } 1981.4 \text { to } 1983.10 \\
\text { From } 1983.11 \text { to } 2006.12\end{array}$ & $\begin{array}{c}\text { no } \\
\text { yes } \\
\text { no } \\
\text { yes }\end{array}$ & $\begin{array}{l}\text { low: yes } \\
\text { high: yes } \\
\text { low: yes } \\
\text { high: yes }\end{array}$ \\
\hline $\begin{array}{c}\text { MOROCCO } \\
1963.3-2006.12\end{array}$ & $\begin{array}{l}\text { From } 1963.3 \text { to } 1978.9 \\
\text { From } 1978.10 \text { to } 2006.12\end{array}$ & $\begin{array}{c}\text { no } \\
\text { yes }\end{array}$ & $\begin{array}{l}\text { low: yes } \\
\text { high: yes }\end{array}$ \\
\hline $\begin{array}{l}\text { PHILIPPINES } \\
\text { 1963.3-2006.12 }\end{array}$ & $\begin{array}{l}\text { From } 1963.3 \text { to } 1969.3 \\
\text { From } 1969.4 \text { to } 1983.9 \\
\text { From } 1983.10 \text { to } 1990.3 \\
\text { From } 1990.4 \text { to } 1990.10 \\
\text { From } 1990.11 \text { to } 2006.12\end{array}$ & $\begin{array}{c}\text { no } \\
\text { yes } \\
\text { no } \\
\text { yes } \\
\text { no }\end{array}$ & $\begin{array}{l}\text { low: yes } \\
\text { high: yes } \\
\text { low: no } \\
\text { high: no } \\
\text { low: no }\end{array}$ \\
\hline $\begin{array}{c}\text { SOUTH AFRICA } \\
\text { 1963.3-2006.12 }\end{array}$ & $\begin{array}{l}\text { From } 1963.3 \text { to } 1973.1 \\
\text { From } 1973.2 \text { to } 2006.12\end{array}$ & $\begin{array}{l}\text { no } \\
\text { yes }\end{array}$ & $\begin{array}{l}\text { low: yes } \\
\text { high: yes }\end{array}$ \\
\hline $\begin{array}{c}\text { SRI LANKA } \\
1963.3-2006.12\end{array}$ & $\begin{array}{l}\text { From } 1963.3 \text { to } 1972.12 \\
\text { From } 1973.1 \text { to } 2006.12\end{array}$ & $\begin{array}{l}\text { no } \\
\text { yes }\end{array}$ & $\begin{array}{l}\text { low: yes } \\
\text { high: yes }\end{array}$ \\
\hline $\begin{array}{c}\text { TRINIDAD AND } \\
\text { TOBAGO } \\
1963.3-2006.10\end{array}$ & $\begin{array}{l}\text { From } 1963.3 \text { to } 1974.1 \\
\text { From } 1974.2 \text { to } 1990.8 \\
\text { From } 1990.9 \text { to } 1993.4 \\
\text { From } 1993.5 \text { to } 1996.10 \\
\text { From } 1996.11 \text { to } 1999.6 \\
\text { From } 1999.7 \text { to } 2006.10\end{array}$ & $\begin{array}{l}\text { no } \\
\text { yes } \\
\text { no } \\
\text { yes } \\
\text { no } \\
\text { yes }\end{array}$ & $\begin{array}{l}\text { low: yes } \\
\text { high: yes } \\
\text { low: yes } \\
\text { high: yes } \\
\text { low: yes } \\
\text { high: yes }\end{array}$ \\
\hline $\begin{array}{c}\text { VENEZUELA } \\
1963.3-2006.11\end{array}$ & $\begin{array}{l}\text { From } 1963.3 \text { to } 1970.5 \\
\text { From } 1970.6 \text { to } 1974.6 \\
\text { From } 1974.7 \text { to } 1985.12 \\
\text { From } 1986.1 \text { to } 2006.11 \\
\end{array}$ & $\begin{array}{c}\text { no } \\
\text { yes } \\
\text { no } \\
\text { yes }\end{array}$ & $\begin{array}{l}\text { low: no } \\
\text { high: no } \\
\text { low: yes } \\
\text { high: yes } \\
\end{array}$ \\
\hline
\end{tabular}

Notes

a. REER: real effective exchange rate.
b. yes: evidence of instability in the variance of the real exchange rate at $5 \%$ significant level, no: no evidence of instability in the variance of the real exchange rate at $5 \%$ significant level.

b. yes: evidence of instability in the variance of the real exchange rate at $5 \%$ significant level, no: no evidence of instability
c. Shadow cells indicate that periods with evidence of instability present an higher volatility than more tranquil periods. 
Table 5(e): Exchange-Regime Duration Effects on Volatility

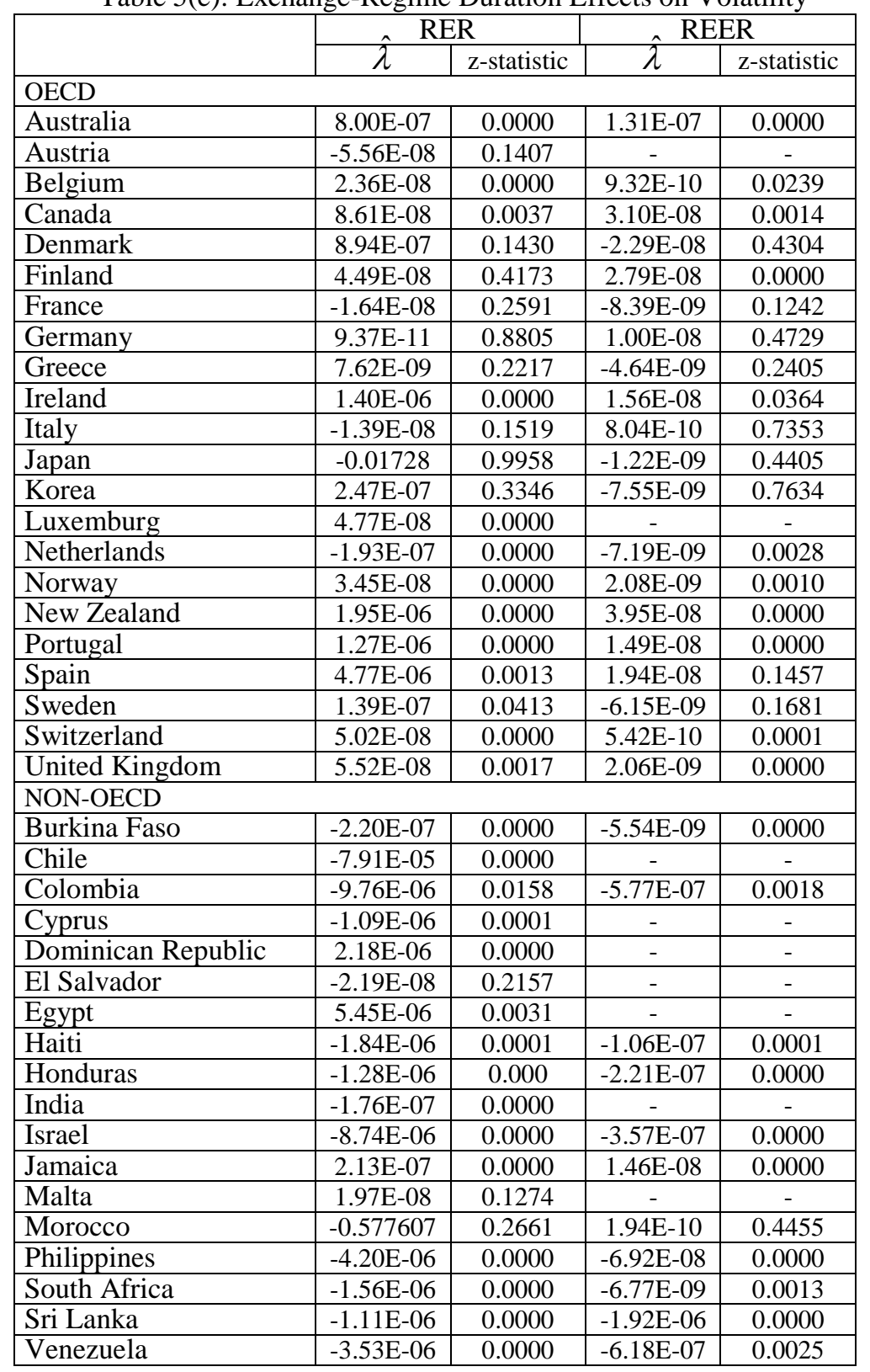



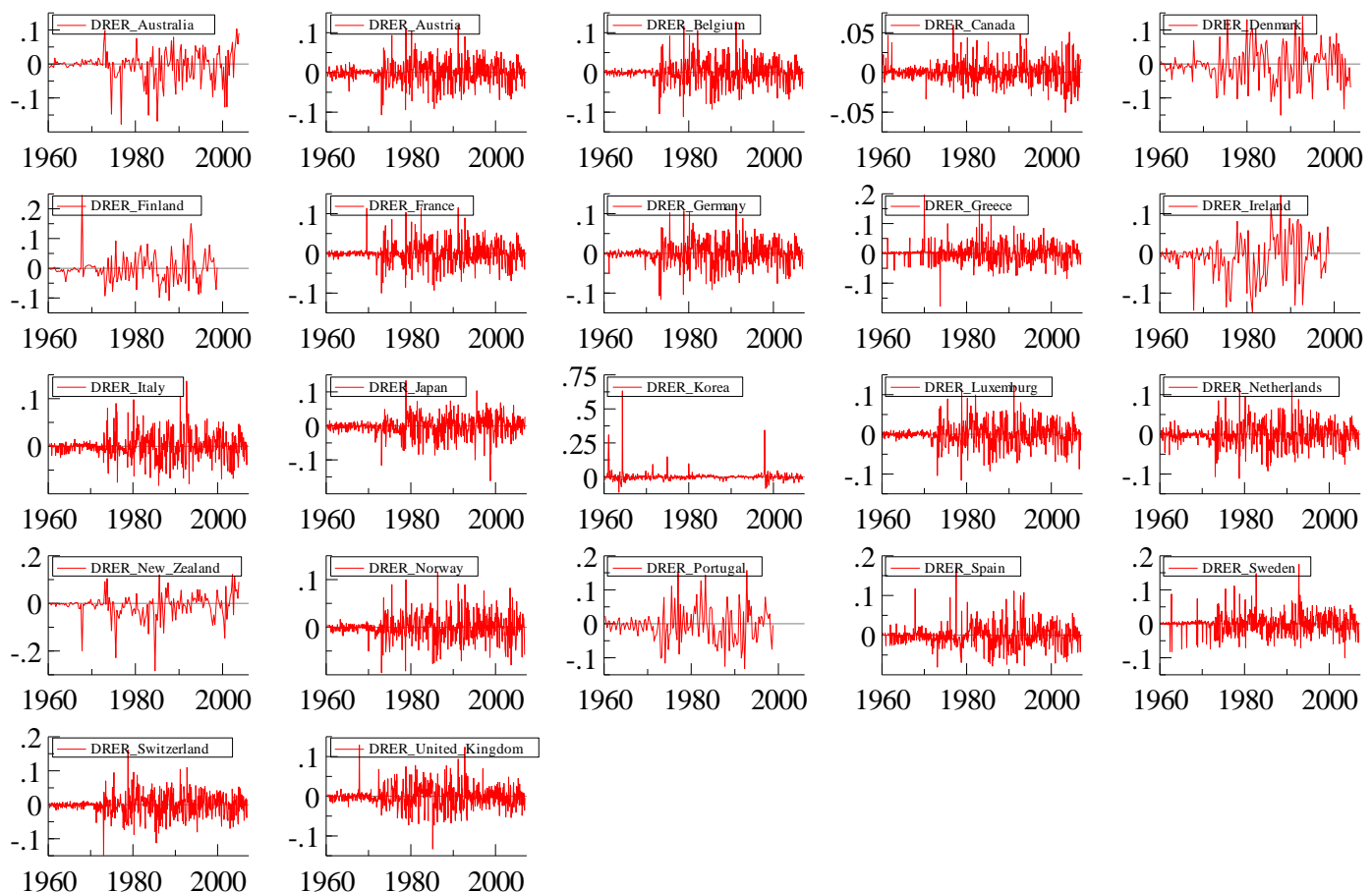

$1960 \quad 1980 \quad 2000$

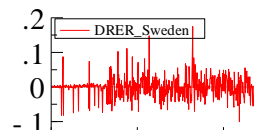

$1960 \quad 1980 \quad 2000$

$19601980 \quad 2000$

$1960 \quad 1980 \quad 2000$

Figure 1 (a). Monthly/Quarterly rate of change in OECD countries real exchange rates against the United States Dollar, 1960-2006. 

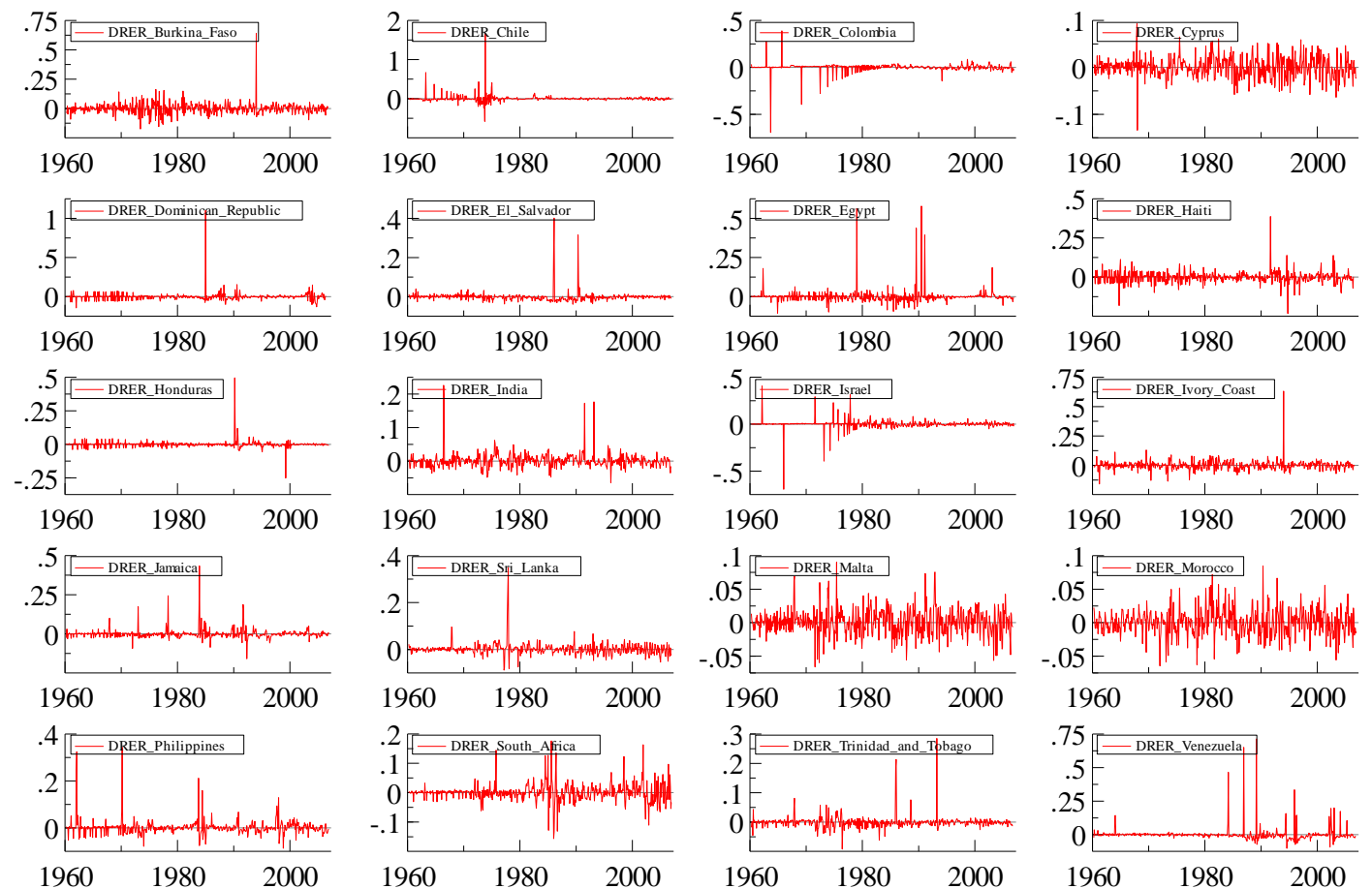

Figure 1 (b). Monthly rate of change in non-OECD countries real exchange rates against the United States Dollar, 1960-2006. 

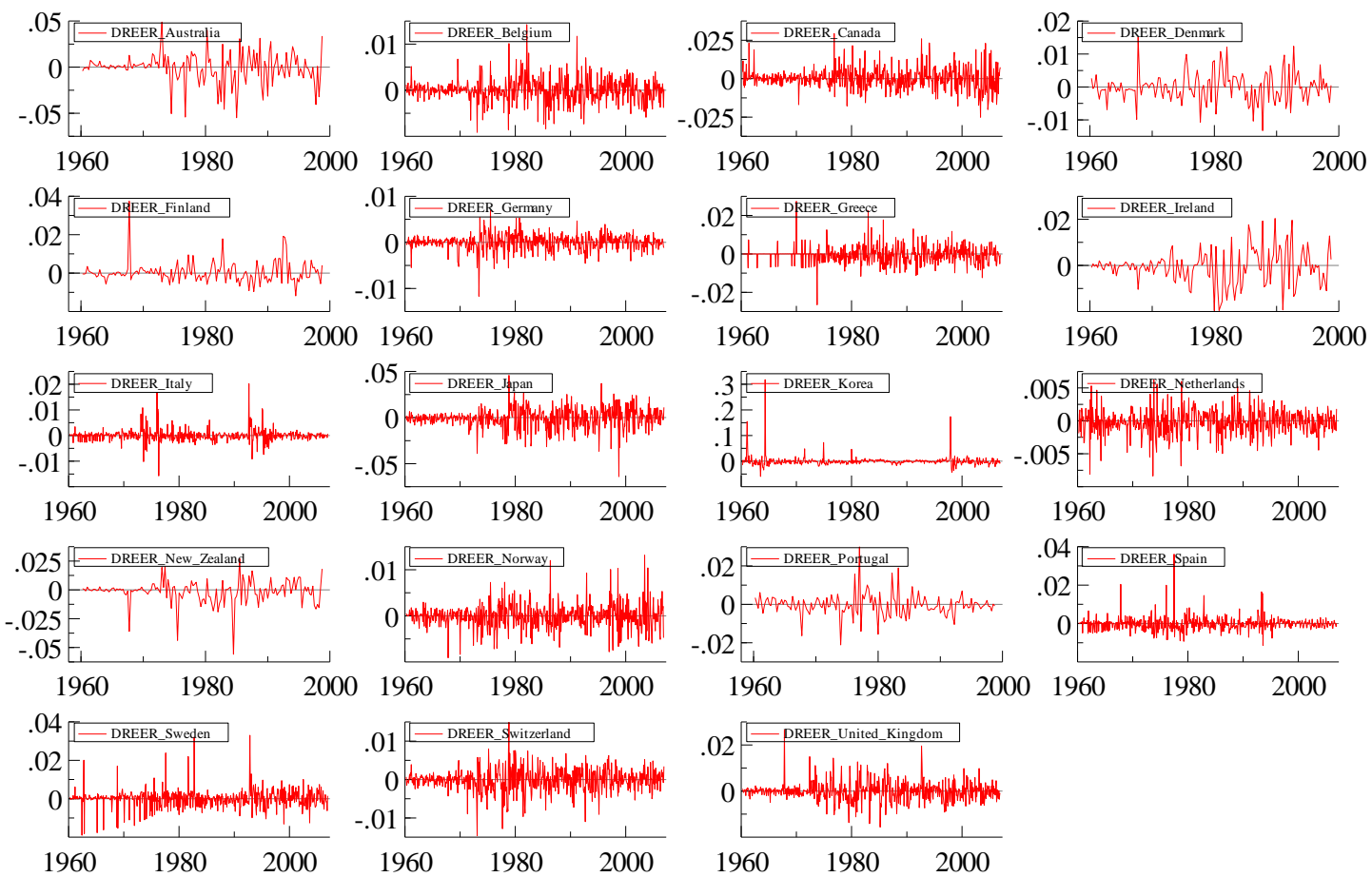

Figure 2 (a). Monthly/Quarterly rate of change in OECD countries real effective exchange rates 1960-2006. 

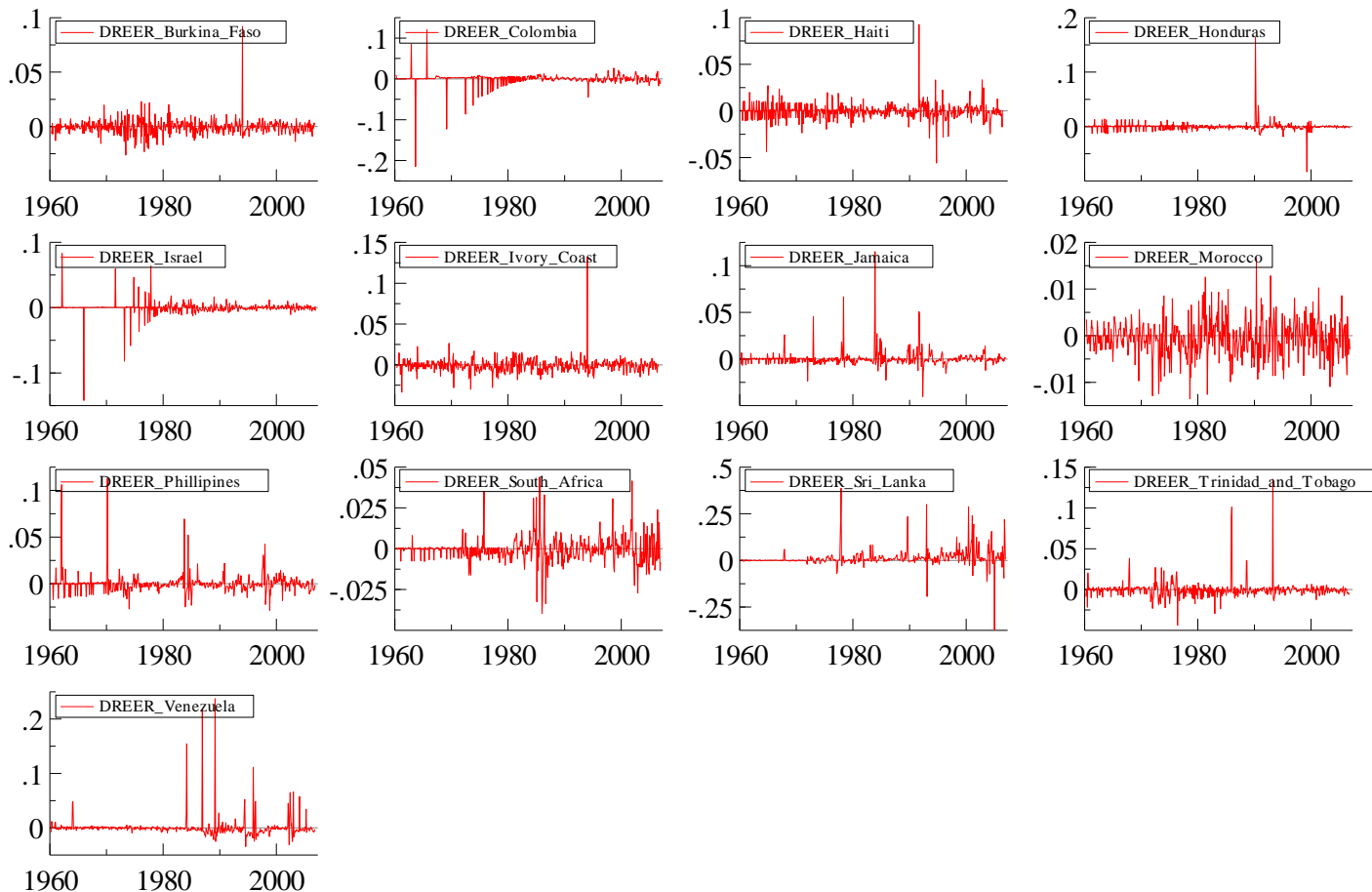

Figure 2 (b). Monthly rate of change in non-OECD countries real effective exchange rates 1960-2006. 

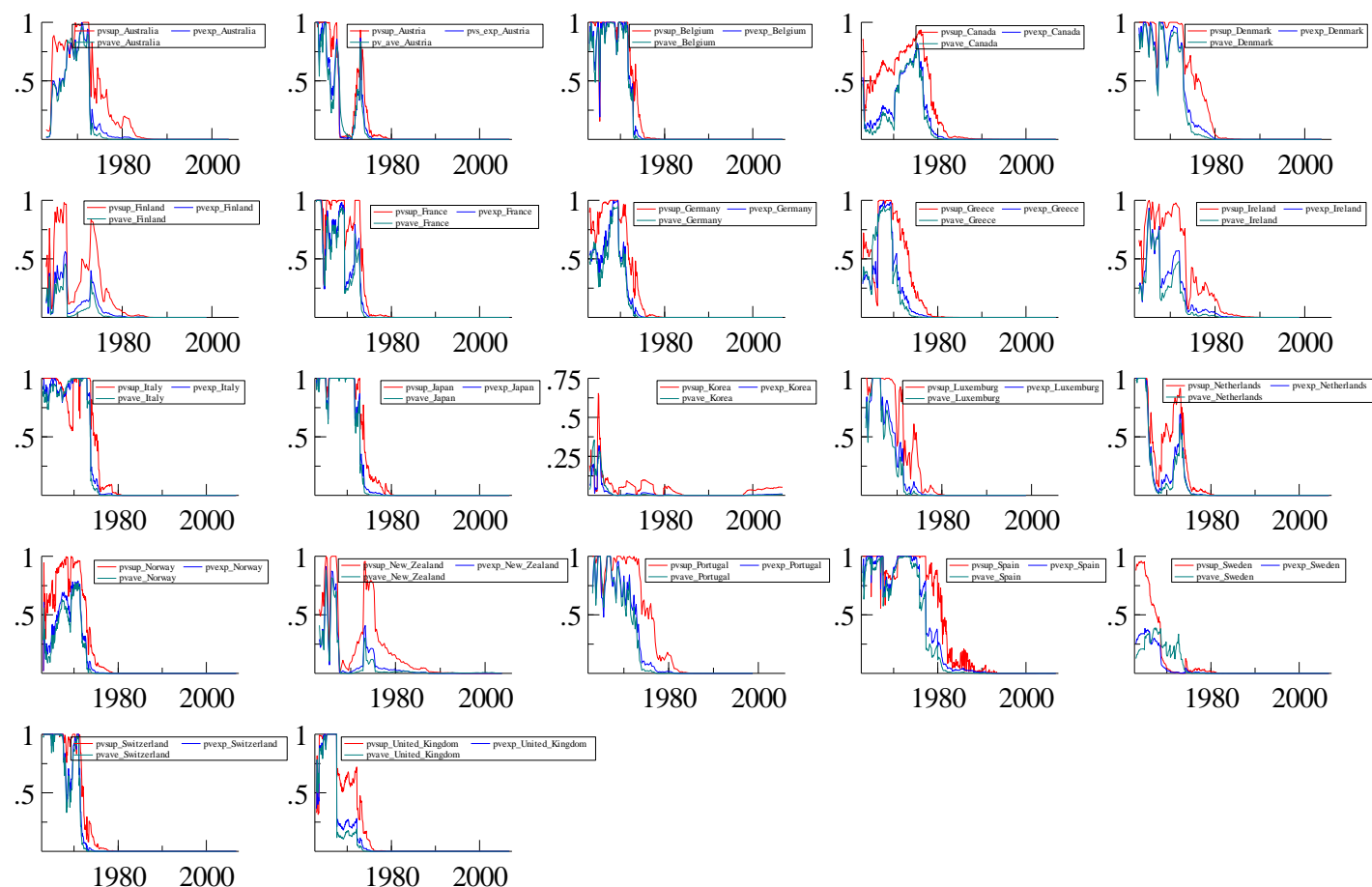

Figure 3 (a). OECD real exchange rates p-values of the supreme (pvsup) test developed by Andrews (1993) and the exponential (pvexp) and average (pvave) tests developed by Andrews and Ploberger (1994), 1963-2006. 

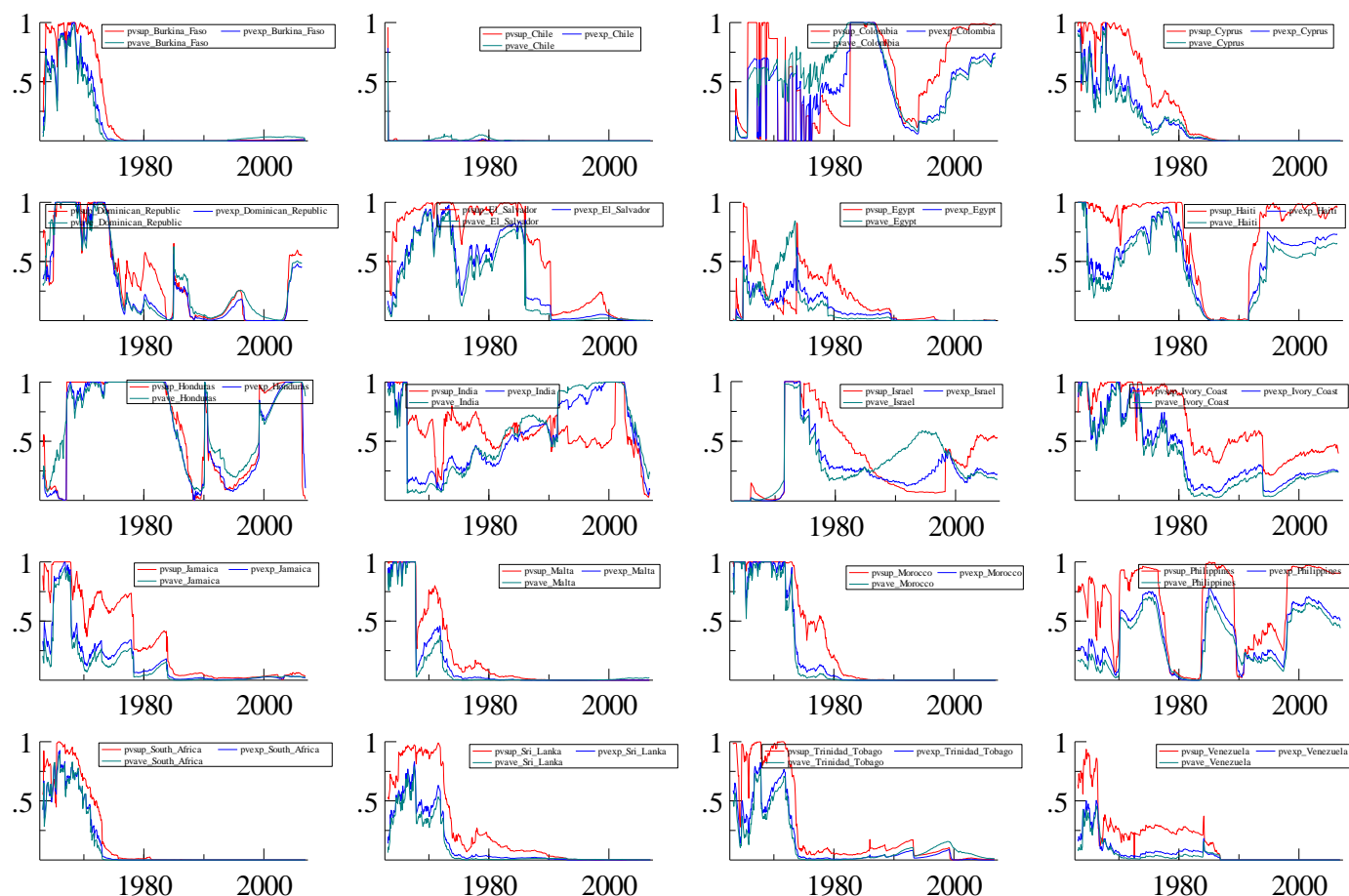

Figure 3 (b). Non-OECD real exchange rates p-values of the supreme (pvsup) test developed by Andrews (1993) and the exponential (pvexp) and average (pvave) tests developed by Andrews and Ploberger (1994), 1963-2006. 

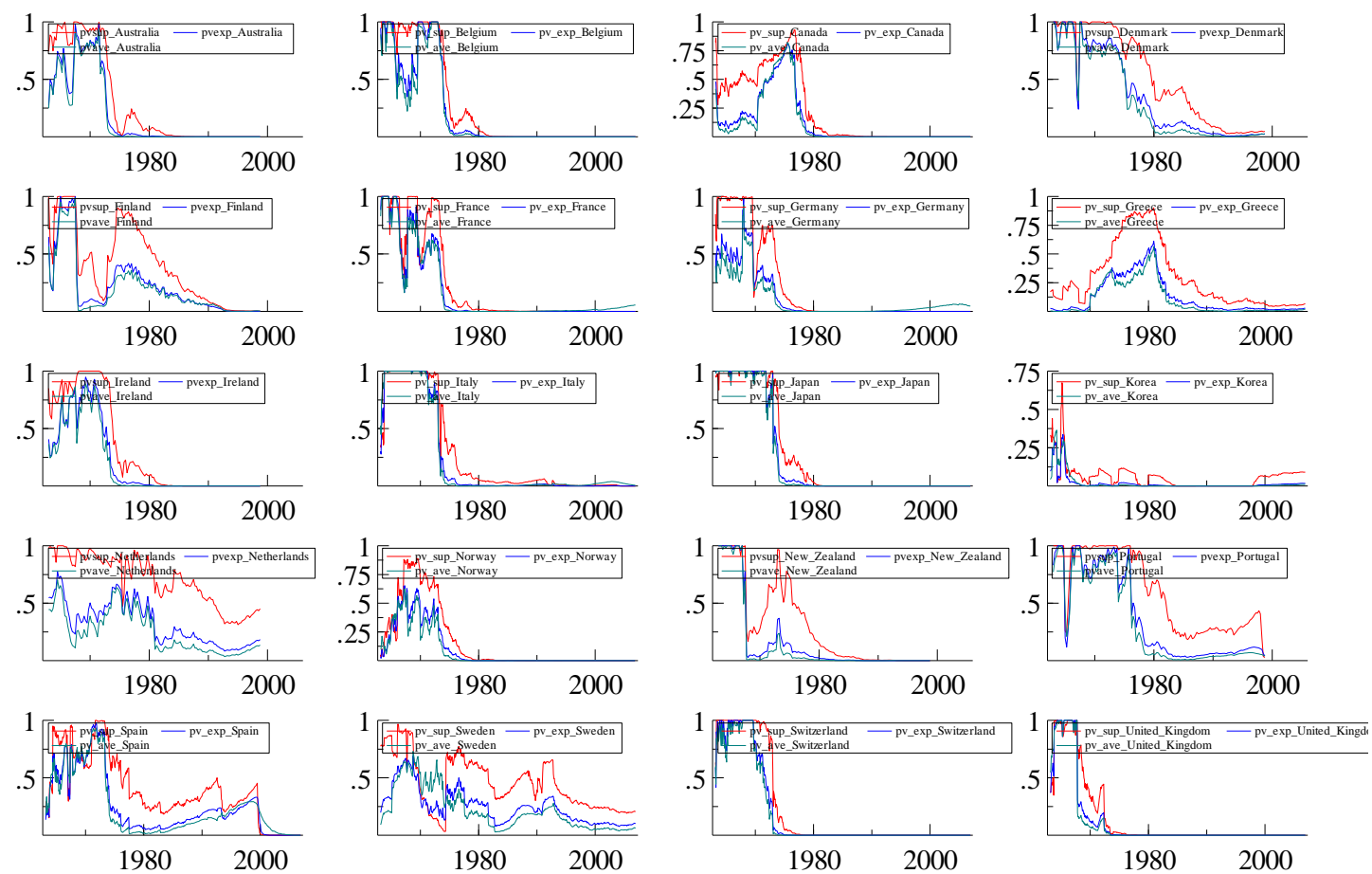

Figure 4 (a). OECD real effective exchange rates p-values of the supreme (pvsup) test developed by Andrews (1993) and the exponential (pvexp) and average (pvave) tests developed by Andrews and Ploberger (1994), 1963-2006. 

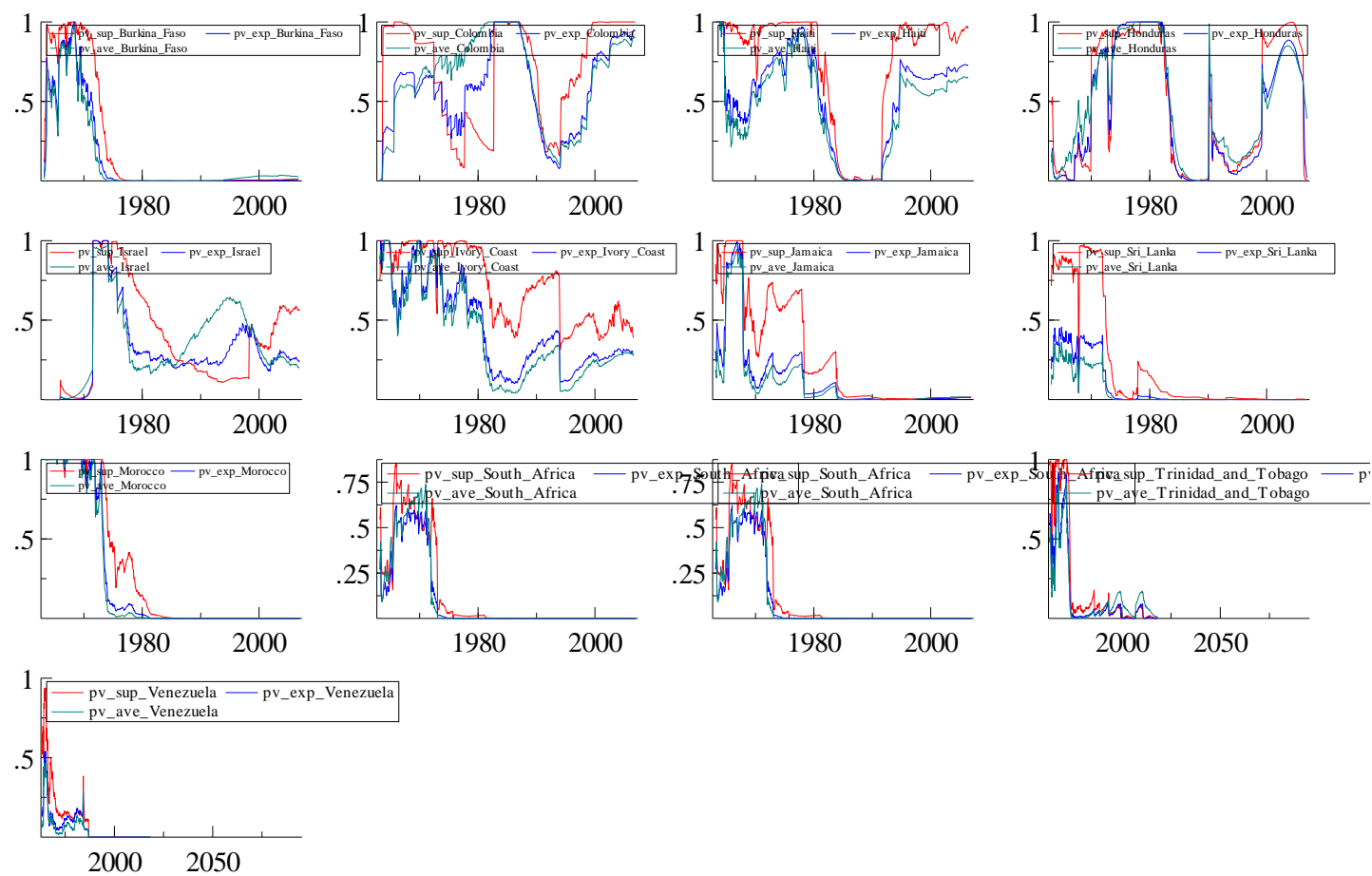

Figure 4 (b). Non-OECD real effective exchange rates p-values of the supreme (pvsup) test developed by Andrews (1993) and the exponential (pvexp) and average (pvave) tests developed by Andrews and Ploberger (1994), 1963-2006. 